\title{
Kırım Tatarcası Dilbilim ve Dilbilgisi Terimleri
}

\author{
Doç. Dr. Ülkü Çelik Şavk*
}

Bu çalışımada, Kırım Tatarcasının dilbilim ve dilbilgisi terimlerinin, dil terimleri ve gramer kitaplarından tespit edilebilenleri, Türkçe ve Rusça karşılıklarıyla birlikte yer almaktadır. Ayrıca, Türkçe ve Rusça terimlerin dizinleri de, karşılaștırmalı çalışanlara kolaylık olsun diye verilmiștir.

\section{Kaynakça}

E. Akmollayev, Kırımtatar tiliniñ ameliyatı, Taşkent, 1989.

Ülkü Çelik Şavk, "Türk Dünyası Gramer Terimleri Kılavuzuna Ek-2 Kırım Tatarcası Gramer Terimleri”, Türk Dünyast-Dil ve Edebiyat Dergisi, Sayı:10, s. 553-576, Güz 2000.

Türkçe-Kazakça-Karakalpakça-Rusça-İngilizce Karşılaştırmalı Dilbilim ve Dilbilgisi Sözlüğü, Ankara, 2001.

Emine Gürsoy Naskali, Türk Dünyası Gramer Terimleri Sözlü̆̆ü, Türk Dil Kurumu Yayınları: 667, Ankara, 1997.

Mehmet Hengirmen, Dilbilgisi ve Dilbilim Terimleri Sözlüğü, Ankara 1999.

Ahmet Kocaman, "Dilbilim Terimleri", Dilbilim Araștırmaları, s. $157-190,1990$.

“Dilbilim Terimleri Sözlüğü - Ek", Dilbilim Araştırmaları, s. 146147, 1992.

Prof. Dr. Zeynep Korkmaz, Gramer Terimleri Sözlüğü, Türk Dil Kurumu Yayınları: 575, Ankara, 1992.

Alaaddin Mehmedoğlu, Ahmet Buran, Hatice Alaaddin Kızı, Karşılaş̧ırmall Dilbilgisi Terimleri Sözlüğü: Türkiye Türkçesi, Azerbaycan Türkçesi, Rusça, İngilizce, İzmir 1994.

\footnotetext{
* Hacettepe Üniversitesi, Fen-Edebiyat Fakültesi Türk Dili ve Edebiyatı Bölümü Ögretim Üyesi.
} 
A.M. Memetov, Kırımtatar tili, Akmescit, Kırımdevokuvped-neşir 1997.

Ayşe Pamir Dietrich, Rusça-Türkçe Dilbilim Terimleri Sözlüğü, Ankara 1997.

Russko-Krımskotatarskiy Terminologiçeskiy Slovar' (Yazık), Simforopol', 1992.

Prof. Dr. Berke Vardar yönetiminde Prof.Dr. Nüket Güz, Prof.Dr. Emel Huber, Prof. Dr. Osman Sanemoğlu, Doç. Dr. Erdim Öztokat, Açıklamalı Dilbilim Terimleri Sözlüğü, İstanbul, 1998.

Hamza Zülfikar, Terim Sorunları ve Terim Yapma Yolları, TDK Yayınları: 569, Ankara 1991.

a

abbreviatura kısaltma аббревиатура

abstrakt soyut абстрактный

abstrak fiil' soyut fiil, soyut eylem глагол абстрактный

abstrak isim soyut ad, soyut isim имя сушествительное, гушегтвительное абгтрактное

abstark mana soyut anlam :значение абстрактное

abzats paragraf аб:зац

açık eca açık hece открытый слог, слог открытый

ad ad на:ввание

adiy cumle basit tümce, yalın cümle, yalın tümce простоe

предложение, предложение простое

adiy haber basit yüklem, yalın yüklem сказуемое простое

adiy zaman basit zaman простое время

aenkdeşlik uyum гармония

affiks çekim eki, ek, hal eki, takı аффикс, окончание

ağız ağız говор, рот

aġız boşluğı ağız boşluğu, avurt, yan боковой, пологть рта

ag̀ız boşlugì ogi öndamaksıl передненёбный

aġız boşlugì sesi avurt sesi боковой звук

aġız boşluġı tutuḳları art avurt ünsüzü боковой согласный

ag̀ız boşlugı ogi tutuḳı ön avurt ünsüzü мягкий боковой согласный 
aġız sesi ağız sesi ротовой звук

ag̀ız sesine keçüv ağızlaşma преврашениев ноцового вротовое ağız tili konuşma dili, nutuk dili устная речь

ag̉ıznıñ açılışı ağzın açılma derecesi pactвop рта

agglütinativ til bağlantılı dil, bitişimli dil, eklemeli dil агглютйнативный язык

akraba til akraba dil родсвенные языка

aktiv etken актив

aktiv fiil' etken eylem, etken fiil актывный глагол

aktiv lugat aktif sözlük активный словарь

aktsent şive, vurgu акцент

akustika akustik, işitimsel акустика

al durum, hâl, tümleç обстоятельство, дополнение, падеж

al affiksi durum eki, durum takısı окончание падежное

al añlatḳan fiil' ulaç, zarf fiil глагол связка

al sözü tümleç обстоятельство, дополнение

al zarfi, tarz alı durum belirteci, hal zarfı, niteleme belirteci наречие образа действия

a-laşk̦an a-okunuş аканье

alfavit abece, alfabe алфавит

alfiil' ulaç, zarf fiil герундив, деепричастие

alınma aktarım, aktarma, alıntı, ödünç : аимствование

almaştırılgan mana mecazî anlam, yan anlam переносное значение

alt çenge alt çene нижняя челюгт

alt dudak alt dudak нижняя губа

alamet özellik призннак

analiz analiz, çözümleme анали:

ana til' temel dil, kök dil, ana dil праязык

ana tili ana dili родной язык, язык родной

- anlam avuşturuv anlam aktarması перенос значения

antiteza karşı tez антите: ‘

antonim karşıt anlamlı, zıt anlamlı антоним

apostrof kesme işareti anor.троф

argo argo арго

arhaizm eski biçim архаизм

arif harf буква

artikulyatsiya boğum!ama, eklemleme артикулянњя 
artikulyatsiya yeri boğumlanma noktası, eklemleme noktası мегто артикуляшия

art sıra arka sıra, art sıra, kalın sıra задый ряд

art sırag̉a keçüv artlaşma, kalınlaşma переход в задний ряд

art sıra sozuk art sıra ünlüsü з заный гласный

arttıruv derecesi en üstünlük derecesi превосхходная степень

asil mana temel anlam основное значение

asıl sıfat niteleme sıfatı качегтвенное прилагательное

asıl haber temel yüklem главное сказуемое

asıl sozuk temel ünlü огновное гласные

asil urgu ana vurgu, temel vurgu огновне ударение, главное ударение

asliy mana temel anlam значение основное

asliy ses aslî ses, birincil ses первоначалышый звук

asliy sıfat niteleme sıfatı качегтвенное прилагательное

asliy uzunlı̣ aslî uzunluk, birincil uzunluk первичная долгота

aspekt görünüş аслект

assimilyatsiya benzeşme ассиииляция

aşag̀ı çenge alt çene нижняя челюст

aşağı dudaḳ alt dudak нижняя губа

atalar sözü atasözü, ata sözü пословища

avam halḳ tili halk sözcüğü прогторечие

ayırıcı ara, belirten, niteleyen, tamlayan, sınır, niteleyici определение, разграничителыый

ayırıcı-umumileştirici zamir niteleme adılı, niteleme zamiri местонмение определителние

ayıruv bağlayıcısı karşılaştırma bağlacı сою3 ра..ıелительный

ayrı manalı önemli, tam anlamlı знаменателыный

ayrı manalı söz bağımsız sözcük знамепателыне словя

aytılıs söyleyiş, telâffuz прои:ıошение

az mahssullı suffiksler işlek olmayan ekler непродуктивные аффиксы aza öge чле॥

azlaştırma manası küçültme anlamı уменшительное зиачение 
b

baġ bağıntılama, bağlama, bağlantı, koşaç гвя.ıь, свя.зКа

bag̉layıcı bağlaç roю:s

bag̉layıcısızlık bağlaçsızlık бегсоюзный

bala tili çocuk dili я.зык детей

baş ana, asıl, temel главный

baş al yalın durum, yalın hal именительный падеж

baş aza asıl öge, baş öge член главный

baş cumle ana cümle, ana tümce, temel cümle, temel tüm главное предложенне

baş keliş yalın durum, yalın hal именительный падеж, падеж именительный

baş ses ilk ses, önses ната.льный звук

baş ses tüşüvi önses düşmesi выпадение начального звука

bel'gisizlik zamiri belgisizlik adılı, belirsizlik zamiri местоимение · неопределёнение

belgili isimli söz biriküvi belirli ad öbeği, belirli isim tamlaması оформленное определительное

belgili tamamlayıcı belirli nesne, belirtili nesne оформленное прямое дополнение

belgisiz belgisiz, belirsiz неопределённый

belgisiz derece edilgen çatı, pasif пассив, залог гтрадательный

belgisiz fiil' edilgen eylem, edilgen fiil, pasif fiil глаголв стралетельном :жлоге

belgisiz isimli söz biriküvi belirsiz isim tamlaması, belirtisiz неоформленное определительное

belgisiz tamamlayıс belirsiz nesne, belirtisiz nesne неоформленное прямое дополнение

belgisizlik zamiri belirsizlik zamiri неопределение мегтоимение

belli şaḥıslı cumleler öznesi belli cümle определённо-личное предложение

beñzetüv yalgaması benzerlik eki, benzetme eki уподобительный аф)икс:

bir azalı cumle tek ögeli cümle одночленное предложение

bir ecalı tek heceli моногиллаб, односложный

bir manalı tek anlamlı однозиачный

bir manalılık tek anlamlılı о.ноначногть

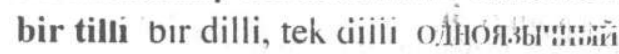


bir tilli lugat tek dilli sözlük одноязычный словарь, словарь одноязыческий

birinci şahıs birinci kişi, birinci şahıs лишо первое, первое лйо

birinci şahııs mulk birinci şahıs iyelik eki аффиксы принадлежности первое лицо

birleşme birleşme, birleşim сочетание

bitken al bitmişlik durumu совершенный вид

bitken vaziyet bitmişlik durumu совершенный вид

boġaz boğaz, boğazsıl, gırtlak, hançere гортань, гуттурал

boġazlaşuv boğazsıllașma гуттурализация

burunlı genizsil, burunsıl. носовой

burunlı ses geniz sesi, genizsil ses носовой звук

burun n'si arka damak n'si, geniz n'si заднеязычный н

burun sesi geniz sesi звуки ноговые

burun tutukları genizsil ünsüzler, nazal ünsüzler назальные гогласные

buyük arif baş harf заглавная

c

canlı canlı одушевлённый

canlı til' canlı dil, yaşayan dil живой язык, язык живой

canlılık canlılık одушевлённость

cevap cumlesi cevap cümlesi ответное предложение

cevap-tasdik nidası cevap ünlemi утвердительное меж домегие

cins cins, cinsiyet род

conıs isim cins ad, tür adı нарицательное сушествительное

cons isim cins isim имя нарицателное

cumle cümle, tümce предложение

cumle azaları cümle ögeleri, cümle unsurları члены предложения

cumle azalarımıñ sıralanması cümle ögelerinin sıralanışı раслоложение членов предложение

cumle intonatsiyası cümle tonu, tümce ezgisi интонашия предложения cumle kuruluşı cümle yapısı строение предложения cumle manası cümle içi anlam значение предложения cumle urgusı cümle vurgusu, tümce vurgusu фразовое ударение cumleniñ baş azaları cümlenin temel ögeleri главные улены предложение

cumleniñ temeli cümlenin temeli основа предложение 
c

çenge çene челюст

çırmaşķan yazı birleştirmeli alfabe, bitişik yazı вя.3ь

çıḳış alı ayrılma durumu, ayrılma hali, çıkma hali, çıkma dur исходный падеж

çı̣ış keliş çıkma durumu, ayrılma hali падеж исходный

çıḳış kelişi ayrılma durumu, ayrılma hali, çıkma hali, çıkma durumu исходный падеж

çift dudaḳlı çift dudak, çiftdudaksıl, dudaksıl билабиальный

çift dudak tutuḳları çift dudak ünsüzü билабиальный согласный

çift söz çift sözcük парные слова

çift tutuḳlar çift ünsüzler парные соглйа̀сные

çoḳ azalı çok ögeli многочленный

çok azalı cumle çok ögeli cümle многочленное предложенное

çok ecalı çok heceli многосложный, полисиллабический

çołluk affiksi çokluk eki аффикс множественности

coḳluk.yalgaması çokluk eki аффикс. множественности

çok manalı çok anlamlı полисемантический

çok manalılık çok anlamlılık многозначность, полисемия

çok tilli çok dilli многоязычный

çok tillilik çok dillilik многоязычие

, "y yazısı resim yazısı клинопись

d

defis kısa çizgi, tire дефис:

delabializatsiya düzleşme делабиализация

deñişme değişim, değişme изменение

deñişüv değişim, değişme изменение

derece çatı, fiil çatısı залог глагола, залог

derecelik ilgeç, edat, son takı послелог, частица

dialektolog lehçe bilimci диалектолог

dialektologiya lehçe bilim диалектология

diaog diyalog, ikili konuşma диалог

diftong çift ünlülü, diftong дифтонг

dikte (imlya) dikte, yazdırma диктант

dissimilyatsiya aykırılaşma, benzeşmezlik диссимиляция

doġrı mana temel anlam основное значение 
doġu yazuv imlâ, yazım правописание dogrudan doğru açık, direkt, dolaysız прямой dogrultuv keliş datif hali, verme durumu, yaklaşma hali,yönelme durumu, yönelme hâli падеж дательный, направительный падеж

dudak dudak губ

dudaḳlaşuv dudaksıllaşma, yuvarlaklaşma огубление

dudaḳlı dudaksıl, yuvarlak губной, лабиальный

dudaḳlı sozuḳ dudaksıl ünlüler, yuvarlak ünlü лабиальные гласные

dudaḳlı sozuk yuvarlak ünlü губные гласные

dudaḳlı tutuk dudak ünsüzü губной согласный

dudaḳlı tutuk dudaksıl ünsüzler пабиальные согласные

dudaḳ sesine keçüv dudaksıllaşma, yuvarlaklaşma лабиализация

dudak singarmonizmi dudak benzeşmesi dudak uyumu лабиальный сингармонизм

dudaḳsız sozuḳ düz ünlü негубной гласный, нелабиализованный гласный

dudaḳ-tişli diş dudaksıl губно-зубной

e

eca hece, seslem слог

еca ayırıcı hece bölmesi, hece sinırı слогораздел

eca biriküvi hece kaynaşması опрешение слогов

eca tüşüvi hece düşmesi, hece yitimi, seslem yutumu гаплопогия, опушение слога

ecnebiy sözler yabancı kelime, yabancı sözcük иногтранное слово

edebiy edebî литературный

edebiy til' edebî dil, yazı dili, yazın dil литературный язык, ялык литературны. художественный язык

eki azalı cumle Ł̧lt ögeli cümle, iki ögeli cümle предложение двугоставно

eki ecalı iki heceli лвуслоговой

eki ecalı sözler iki heceli sözcükler двусложные слова

eki haberli cumle ii.i yüklemli cümle двусказуемое предложение

ski manalılı iki anlamlılık двазначногть

eki muptedalı cumle iki özneli cümle двуподлежашпе предюжене 
eki noḳta iki nokta двоеточное

eki tilli lugat iki dilli sözlük двуязычний словарь

eki tillilik iki dillilik двуязычие

ekilik sayı çift sayı двойственное писло

ekinci derece aza ikinci dereceli öge член второстепенный

ekinci derece haber ikili çatılı yüklem второгтепенное гказуемое

ekinci şahıs ikinci kişi лишо второе, второе лишо

ekinci şaḥıs çoḳluḳ çoğul ikinci kişi, ikinci çoğul kişi второе лишо множегтвенного число

ekinci şaḥıs teklik ikinci tekil kişi, ikinci teklik şahıs второе лишо единственного число

ekinci uzunlık ikincil uzunluk вторичная долгота

ekvativ ekvatif, eşitlik экватив

elifbe abece, alfabe азбука, алфавит

emir cumlesi emir cümlesi повелительное предложеное

emir meyil buyruk kipi, buyrum kipi, emir kipi императив, повелительное наклонение

entsiklopedik lugat ansiklopedik sözlük эншиклопедический словарь

erkek cınsı eril cins, erkeklik мужской род

eskirgen söz arkaik sözcük, eskimiş sözcük архаи:м, устаревшия Слово

etimologiya etimoloji, kökenbilim этимология

f

fisıltılı ıslıklı шипяший

fisıltılı sesler islıklı sesler шипяшие звуки

fiil' eylem, fiil глагол

fiil' cumlesi eylem tümcesi, eylem cümlesi, fiil cümlesi глагольное предложение, предложение с глагольным гказуемым

fiil' negizi eylem gövdesi, fiil gövdesi глагольная основа, основа глагола

fiil' tamırı eylem kökü, fiil kökü глагольный корень

fiil'den fiil' yapıcı yalgama fiilden fiil yapım eki аффикс: образуюший глагол от глагола

fiil'den fiil' yapuv fiilden fiil yapma внутриглагольне 
fiil'den isim yapıcı yalgama fiilden isim yapım eki аффикс. образуюший имя от глагола

fiilden yapılgan fiil' eylemden türeme eylem, fiilden türeme fiil прои:зводный от глагола глагол

fiilden yapılgan isim eylemden türeme ad, fiilden türeme isim производный от глагола имя

fiil'lerniñ tüslenüvi eylem çekimi, fiil çekimi слряжение глагола

fiil'siz fiilsiz безглаголный

flektiv tiller bükümlü diller, bükünlü diller флективные языки

fonema ses birim, fonem, sesbirim фонема

fonemanıñ türleri alofon, ses birimsel değişke, sesbirimcik, sesbirimsel аллофона fonetika fonetik, sesbilgisi фонетика

fonologiya fonoloji, ses bilimi, sesbilim фонология

forma biçim форма

frazeologik lugat deyimler sözlüğü фразеологический словарь

$\mathrm{g}, \dot{\mathrm{g}}$

garmoniya uyum гармония

geminatsiya ikizleşme геминашия

genealogiyalık kalıtımsal, soydaş генеалогический

girtlak boğaz, gırtlak, hançere гортань

gırtlak sesleri gırtlaksıl sesler гортанная звуки

gurtlak ustü tutuḳlan gırtlaksıl ünsüzler надгортанниковие согласные

giperbola abartma гипербола

gipoteza hipotez, varsayım гипотеза

grammatika dilbilgisi грамматика

h

haber bildirme, yüklem изъявительный, сказуемое, предикат

haber fiili bildirme kiрi изъявительное наклонение

haber ismi yüklem ismi именное гказуемое

haberleşme bildirişim, iletişim коммуникация

haberlik affiksi bildirme eki аффикс: сказуемости

halk tili halk dili народный язык

has isim has isim, özel ad,özel isim имя собственное, собственное имя

hitap hitap, seslenme обрашение 
ibare anlatım, ifade, deyim, söz öbeği выражение, оборот речи, фра:ха

içki iç, içsel внутренный

içki rifma iç kafiye, iç uyak внутристрочная рифма

içki ses iç ses, içses инлаут

idare yönetim, yönetme управление

idare bağ1 yönetim, yönetme управление

idare etici söz yönetici sözcük управляюшее слово

idiolekt birey dili, bireysel dil идиолект

idioma deyim идиома

ifade anlatım, ifade выражение

ikaye cumlesi bildirme cümlesi, bildirme tümcesi повествовательное предложение

ikaye meyli bildirme kipi и:ъъвительное наклонение

ilave ek ad koyma, eşleme приложение

il'miy til' bilim dili научный язык

imla imlâ, yazım, yazım kuralları орфография, правописание

ince ince мягкий

ince sesler ön sesler звуки мягкие

ince sira ince sira передний ряд

ince sozuk ince ünlü, őn ünlü гласные мягкие, мягкие гласные

ince tutuk ince ünsüzler мягкие гогласные

indeks dizin, indeks индекс:

infinitiv mastar, isimfiil инфинитив

informant bilgi veren, denek информант

inkar sözleri olumsuzluk отришание

inkar zamiri olumsuzluk zamiri, olumsuzluk adılı отрицательное местоимение

internatsional' sözler uluslararası sözcük интернашиональные слова

intonatsiya titremleme интонация

inversiyalı cumle devrik cümle инвертированное предложение

ironiya ironi ирония

isim ad, isim имя, название, сушествительное

isim cumlesi isim tümcesi предложениегименнымсказуемым

isim negizi ad gövdesi, isim gövdesi именная основа 
isim söz birikmesi isim tamlaması словосочетание именное isim söz birleșmesi isim tamlaması словогочетание именное isim tamırı ad kökü пепроизводное сушествительное isimden türeme isim addan türeme ad, isimden türeme isim производный от имены имя

isimden yapılgan fiil addan türeme eylem, isimden türeme fiil прои:зводный от имены глагол

isimfiil' isim fil, kılış ismi, mastar глагольное имя, инфинитив

ismiñ türlenüvi isim çekimi склонение сушествительног

ismiy cumleler ad tümcesi, isim cümlesi именное предложение

istek cumlesi istek cümlesi, dilek cümlesi желательное предложение

istek meyil istek kipi желательное наклонение

ișaret belirtke, ișaret знак

ișaret sıfatı gösterme sıfatı, işaret sıfatı ука.ательное слово

işaret zamiri gösterme adılı, işaret zamiri указательное мегтоимение, местоимение указательное

izafet izafet изафет

izaiy lugat ansiklopedik sözlük толковый словарь

j

jargon jargon жаргон

jargonizm jargonizm жаргонизм

jestler tili işaret dili язык жестов

$\mathrm{k}, \mathrm{k}$

ḳaçaḳ akıcı беглый

ḳaçak sesler akıcı sesler беглыйе звуки

ḳaçaḳ sozuḳ akıcı ünlü беглый гласный

kadın cınsı dișilik женский род

kaide düzenleme, kural правило

kalıcı geçişsiz непереходный

kalıcı fiil' geçișsiz fiil глагол нелереходный

kalın sozuk art sıra ünlüsü заный глак:ный

kaltıravụk tutuḳ titremeli ünsüz, titrek ünsüz, titreşimli ünsüz дрожаший согласный

kapalı e kapalı е қакрытый э 
kapalı eca kapalı hece закрытый слог

ḳarama ḳarşı sözler karşıt anlamlı, zıt anlamlı антоним

ḳarşı ḳuyuv bağlayıcısı karşıtlık bağlacı, karşıtlık ilgeci, zıtlık bağlacı союз противительный, противительный союз

karşı manalılık zıt anlamlılık антонимия

kattı art avurt, sert твёрдый

ḳattı sozuḳ art sıra ünlüsü задный гласный

kattı tañlay sert damaksıl твёрдонёбный

ḳattı tutuḳ art avurt ünsüzü, sert ünsüz твёрдый согласный

ḳavuz ayraç, parantez скобка

kaytım dönüşlülük возвратный

ḳaytım derece dönüşlü çatı возвратный залог, залог возвратный

ḳaytım fiili dönüşlü eylem, dönüşlü fiil возвратный глагол, глагол во.звратный

ḳaytım zamiri dönüşlülük adılı, dönüşlülük zamiri возвратные местоимения

kakafoniya kakışma, kakofoni, ses uyumsuzluğu какафония

kal'ka kopya, öykünme, taklit калька

keçici fiil' geçişli fiil глагол переходный, глагол транзитивный

keçiş geçiş, geçme переход

keçken zaman geçmiş zaman прошедшее время, время прошедшее, перфект

keçüv geçiş, geçme переход

kelecek zaman gelecek zaman, geniş zaman будушее время, время будушее

keliş durum, hâl падеж

keliş affiksi durum eki, durum takısı аффиксы падежей, окончание падежное

kemirçek sesine keçüv gırtlaksıllaşma преврашениев гортанный звук

keniş cumle genişletilmiş cümle раслространённое предложенное

keñ sozuk geniş ünlü широкий гласный

kerek meyil gereklik kipi, gereklilik kipi долженствовательное наклоненение

kesir sayılar kesir sayı sıfatları дробное числительное

kesir sayısı kesir sayısı тислительное дробное

kııḳa kısa краткий 
kısḳa eca kısa hece краткий слог kııḳalık kısalık краткость

kııḳa sozuk kısa ünlü краткий гласный

kısḳartuv kısaltma аббревиатура

kıya laf dolaylı anlatım косвенная речь

ki bağlayıcısı ki bağlacı союз ки

kirilitsa Kiril alfabesi кирилиша

kiriş ara, giriş вводный

kiriş cumlesi ara cümle, aratümce, giriş cümlesi вводное предложение, предложение вводное

kiriş söz ara sözcük вводное слово

klişe basmakalıp, klişe клише

koçürilme laf dolaysız anlatım прямая речь

konkret fiil' somut fiil глагол конкретный

konkret isim somut ad, somut isim конкретное имя, конкретное сушестбительное

konkre:t mana somut anlam значение конкретное, конкретное значение

konteks t bağlam контекст

ḳoşma aiffiks birleşik ek сложный аффикс

ḳoşma dudaḳ tutuḳları çift dudak ünsüzü билабиальный согласный

ḳoşma hạaber birleşik yüklem сказуемое составное

ḳoşuluv kaynaşma стяжение

ḳoşuvcı sızuḳ bağlama ünlüsü соединительный гласный

kuçük ariif küçük harf маленькая буква

ḳuvetlendi rici parçalar kuvvetlendirme edatı, pekiştirme edatı усиилительная частица

kuvetlendirme kuvvetlendirme, pekiştirme усиление

1

lafnıñ stili k:onuşma tarzı стиль разговорный

laringal' tu tuk hemze хам:за

laḳırdı kon uşma, söz разговор, речь

laḳırdı app๕ ıratı konuşma aygıtı речевой аппарат

laḳırdı orgı anları konuşma azaları,konuşma organları, ses örgenleri орг аны речевые 
laḳırdı ritmi konuşma ritmi ритм речи

laḳırdı tili konuşma dili ра:зговорная речь

leksika kelime hazinesi, sözcük dağarcığı, söz varlığı лексика

leksikolog sözcük bilimci лексиколог

leksikologiya sözcük bilgisi, sözlük bilimi лексикология

lingvist dilbilimci лингвист

lingvistika dilbilim лингвистика

logik sub'yekt gizli özne скрытое подлежашее

lugat sözlük словарь

lugat manası sözlük anlamı значение лексическое

lugat terkibi söz varlığı, kelime hazinesi словарный состав языка

m

makssad bildirgen al sözü maksat tümleci обстоятельство цели

maksad bildirgen zarf amaç zarfı, maksat zarfı наречие цели

malüm derece etken çatı залог действительный, действительный залог

mana mânâ, anlam значение, смысл

manadaş eş anlamlı, anlamdaş синонимический

manadaşıł anlamdaşlık, eş anlamlılık синонимия

manadaş sözler anlamdaş sözcükler равнозначный слова

manalı anlamlı значаший

manalılık anlamlılık значимость

mananıñ tarlaşuvı anlam daralması сужение значения

mana türlenüvi anlam değişmesi изменение значение

mantıklı mantıklı логический

mantı̣ urgusı mantık vurgusu логическое ударение

mecul fiil' edilgen eylem, edilgen fiil, pasif fiil глагол в страдетельном : алоге

medeniy kültürel, medenî культурный

menfiy olumsuz отрицательный

menfiy cumleler olumsuz cümle отрицательное предложение

menfiy fiil' olumsuz fiil отрицательная форма глагола

menfiylik sözleri olumsuzluk отришание

menfiy zamiri olumsuzluk adılı, olumsuzluk zamiri местоимение отришательная

metafoniy's ünlü at!amas! метафония 
metafora anlam atlaması, eğretileme, mecaz метафора metafraza aktarma метафра: metastaz metastaz метастаз metateza göçüşme, görünüş, yer değiştirme метатеза mevzu konu, tema тема meyil kiр наклонение miḳdar-derece alı miktar-derece tümleci обстоятельство мерыстепен

mikdar-derece zarfi azlık çokluk zarfı наречие количественное mikdar sayılar asıl sayı sıfatı, asıl sayı количественное числителное mikdar sayısı asıl sayı, asıl sayı sıfatı числительное количественное milliy til' millî dil национальный язык modallik kiplik модальность morfema biçimbirim, şekil birimi морфема morfemanıñ türleri alomorf, biçimbirimcík алломорфа morfologiya biçimbilim, şekil bilgisi морфология mul'kiyet affiksleri iyelik ekleri аффиксы принадлежности mul'kiyet zamiri iyelik adılı, iyelik zamiri мегтоимение притяжательное

munasebetçi ilgeç, edat, son takı послелог mupteda özne подлежашее mupteda haber kelişüvi özne yüklem uygunluğu согласование сказуемого с. подлежашим

muptedasız öznesiz беслодлежашный

muptedasız cumleler öznesiz беслодлежашный предложения murekkep bileşik, birleşik составной murekkep ad birleşik ad, birleşik isim сложное имя murekkep affiks birleşik ek сложный аффикс.

murekkep cumle bileşik tümce, birleşik tümce сложное предложение

murekkep fiil' birleşik eylem, birleşik fiil сложный глагол murekkep haber birleşik yüklem сказуемое составное, составное г.казуемое

murekkep kelecek zamannıñ dayimịlik şekiliniñ vastasız şekili geniş zamanın hikâyesi прошедшее неопределённое время murekkep kelecek zamannın kạtiy şekliniñ şart şekili gelecek

- zamanın şartı будушее условное время 
murekkep kelecek zamannıñ kạtiy şekliniñ vastalı şekili gelecek zamanın rivayeti будушее повествовательное время

murekkep kelecek zamannın ḳatiy șekliniñ vastasız şekili gelecek zamanın hikâyesi будушее намерение

murekkep ḳskartılgan söz kısaltılmış sözcük сложносокрашённое слово

murekkep mupteda birleşik özne составное подлежашее

murekkep söz birleşik kelime, birleşik sözcük сложное слова

musbet cumle olumlu cümle, olumlu tümce утвердительное предложение

musbet fiil' olumlu fiil положительная форма глагола

n

nefes aluv soluk alma вдыхание

nefes çkaruv soluk verme выдох, выдыхание

nefes çıaruv urgusı soluk verme vurgusu выдыхательное ударение

negiz gövde, türemiş, türeme, türev основа, производный

neologizm yeni sözcük неологизм

nida ünlem восклишание, междометие

nida cumlesi ünlem cümlesi, ünlem tümcesi восклишательное предложение, междометное предложение

nida derecelikleri ünlem edatı, ünlem ilgeci частишы восклицсательные

nida intonatsiyası ünlem ezgisi ünlem tonu интонация восклишательная

nida işareti ünlem işareti восклишательный знак, знак восклицательный

nida parçaları ünlem edatı, ünlem ilgeci частишы восклицсательные

nisbiy zamirler ilgi adılı, ilgi zamiri относительное местоимение

nokta nokta точка

noḳtalı virgül' noktalı virgül точка $\mathrm{c}$ : запятой

nominatsiya adlandırma, yalın hal номинашия

nutuk söz речь

nutuḳnı̃ stili konuşma tarzı стиль разговорный 
o

ob'yektli geçişli переходный

ob'yektsiz nesnesiz безобъектный, непереходный

og' sıra ince sıra передний ряд

og' sıra sozuklar ince sıra ünlüler, önsıra ünlüler передние гласные

og' sıraga keçüv incelme переход в передний ряд

ohşav-kuçültüv affiksi küçültme eki уменшительно-ласкательный аффикс.

ohşav yalgaması benzerlik eki, benzetme eki уподобительный аффикс.

ol'çü ve derece zarfi miktar zarfı наречие меры и степени oluv meyli bildirme kipi иъъявительное наклонение

olü ölü мёртвый

olü affiks ölü ek мёртвый суффикс.

olü til' ölü dil мёртвый я.зык

omonim eşadlı омоним

orfoepiya konuşma bilim, ölçünlü söz bilim орфоэпия

orfografiya imlâ, yazım, yazım kuralları орфография

orta cins cinsiyetsiz средний род

ortak haber ortak yüklem обшее гказуемое

ortak mupteda ortak özne обшее подлежашее

ortak ob'yekt ortak nesne обшее дополнение

ortaḳlık karşılıklı, işteş въаимный

ortaḳlık derece iştaş çatı, işteş çatı в:ъамный залог, :алог въаимный ortaḳlık fiil' işteş fiil, işteş eylem, işteş fiil глагол в:аимный

ortaḳlık yalgaması ortaklaşma eki аффикс. совместности

orta tañlay tutuḳı orta damaksıl ünsüz средненёбный согласный

oz'lük zamiri dönüşlülük zamiri, dönüşlülük adılı мегтоимение возвратное

$\ddot{0}$

önimli işlek, üretken продуктивный

önimlilik üretkenlik воглроизводимогть

p

paradigma örneklem парадигма

parça ilgeç частица 
patlayıеı kapantılı, patlamalı, patlayıсı в.рывной patlayıcı sagırlar patlayıcı ötümsüzler в:рывные глухие patlayıcı tutuklar patlayıcı ünsüzler в.рывные согласние patlayıcı yañgiravuḳlar patlayıcı ötümlüler в:рывные :зонкие pauza ara, durak, durma пау:з pay sayı sıfatı üleştirme sayı sıfatı разделительное числителное pısırdilı ses fisıltılı ses шёпотный звук piktogramma resim yazı пиктограмма pozitsiya durum позиция prefiks önek префикс.

progressivlik assimilyatsiya ilerleyici benzeșme ассималяция прогрескивная

proteza bașta ünlü türemesi, ön türeme проте:зa

$\mathbf{r}$

regressivlik gerileyici регрескивный

regresivlik assimilyatsiya gerileyici benzeşme ассимиляция регресгивная, регрегсивная ассимиляшия

resmiy til' resmî dil офишиальный язык

rifma kafiye, uyak рифма

ritorika söz bilim, söz sanatı риторика

$\mathbf{s}$

sade cumle basit cümle, yalın cümle, yalın tümce назывное предложение

sade isim yalın isim имя в основном падеже

sade keçken zamannıñ vastalı şekili öğrenilen geçmiş zaman прошедшее неочевидное время

sag̀ı ötümsüz, sedasız, tonsuz глухой

saġırlaşuv ötümsüzleşme, sedasızlaşma, tonsuzlaşma оглушение

saġırlı̨ ötümsüzlük глухогть

saġır tutuk ötümsüz ünsïz глухой согласный

saiplik keliși ilgi hali, ilgi durumu, tamlayan durumu iyelik durumu, iyelik hali падежродительный, родительный падеж

saiplik kelişi genitif, ilgi durumu, ilgi hali, tamlayan durumu генитив sanlık sayı adı, sayı ismi имя числительное

satır başı paragraf а б:สฺ

sayı sayı, sayı adı, sayı isıni имя числительное, число 
sayı sıfatı sayı sıfatı числительное sebep bildirgen zarf sebep zarfı наречие причины semantika anlambilim, anlam bilimi семантика semasiolog kavram bilimci семасиолог semasiologiya kavram bilim семасиология ses ses голог, звук

ses bezleri ses telleri глоговые связКи

ses biriküvi ses birleşmesi, birleşme, çakışma, geçişme конвергентиия

ses birleşmeleri birikmeleri ses birleşmesi звукосочатание ses deñişmesi ses değişmesi и:зменение звука ses koşuluvı ses türemesi прибавление збука seslerniñ meydanġa kel'mesi sesin oluşumu, sesin türemesi обра:зование :зука

seslerniñ yerlerini almaştıruvı göçüşme, yer değiştirme перегтановка :зуков

sesniñ yüksekligi ses yüksekliği высота звука

ses tonu ses tonu гологовой тон

ses türlenüvi ses değişmesi изменение звука

ses tüşüvi ses düşmesi, ses yitimi падение звука

ses uzunlug̀ı ses uzunluğu долгота :вука

ses yolı ses yolu путь воздуха

sifat sifat имя прилагетелное

sıfat söz birikmesi sıfat tamlaması определительное словосочетание

sıfatfiil' ortaç, partisip, sıfat fiil глагольное прилагігельное, причастие

sira sıra порядок, ряд

sıra sayısı sıra sayısı, sıra sayı sıfatı числительное порядковое

sıż̇ravuḳ tutuḳlar sızıcı ünsüz шелевой согласный

sızıçı̣ çizgi ёрточка

singarmonizm ünlü uyumu сингармони:м

sinkopa iç ses düşmesi, içses düß̧mesi, içses yitimi, iç ses yitimi синкопа

sintaksis cümle bilgisi, sentaks, sözdizimi, tümce bilim синтаксис.

sintaktik dizimsel гинтагматический

skobka ayraç, parantez гжобка

sonorlı ses titreşimli ses сонорный звук 
sonorlı tutuḳlar akıcı ünsüz сонорный согласный soydaş bir cins, türdeş однородный sozuk ünlü, vokal вокоид, гласный sozuḳ ḳısḳalıg̀ı ünlü kısalığı краткость. гласных sozuḳlarnıñ garmoniyası ünlü uyumu гармония гласных sozuklarnı̃ uygunluġı ünlü uyumu гармония гласных sozuḳlaşuv ünlüleşme вокали:зашия

sozuk nevbetleşüvi ünlü almaşması, ünlü göçüşmesi чередование гласных

sozuk türlenüvi ünlü değişimi изменение гласного

sozuk tüşüvi ünlü düşmesi, ünlü yitimi выпадение гласного söylev konuşma pa:‡говор

söylev tili konuşma dili разговорная речь söz kelime, sözcük слово

söz birikmesi kelime grubu, sözcük öbeği словогочетание söz birleşmesi kelime grubu, sözcük öbeği словосочетание söz çeşitleri sözcük türü части речи söz manası düz anlam, sözcük anlamı значение слова söz og'ü yardımcısı ilgeç, edat предлог söz terkibi sözcük birleşimi состав словарный söz türlenüvi sözcük çekimi, sözcük değişmesi словои:зенение söz yapıcı sözcük türetici гловопрои:зводный söz yapıcı affiks yapım eki слювообразовательный аффикс. söz yapuv sözcük türetme, sözcük yарıтı словообразование sözlerniñ ecalarga bölünüvi heceleme, seslemleme прои:ношение по слогам

sözlerniñ sırası sözlük düzeni порядок слог sözniñ asıl manası sözlük anlamı первичное значение sözniñ çoḳmanalılıgıı çok anlamlı sözcük многозначное слово sözniñ doğı manası sözlük anlamı первичное значение sözniñ negizi sözcük gövdesi основа слова sözniñ temeli sözcük gövdesi основа слова stil' biçem, deyiş, tarz, üslup стиль stilistika biçem bilim, deyişbilim, üslup bilimi стилистика sual' soru вопроr. sual' affiksi soru eki вопрогительная частица 
sual' cumlesi soru cümlesi, soru tümcesi вопросительное предложение

sual' derecelikleri soru edatı, soru ilgeci частишы вопросительные sual' intonatsiyası soru ezgisi, soru tonu интонашия вопросительная sual' işareti soru işareti вопросительный знак, знак вогіросителный

sual' parçaları soru edatı, soru ilgeci частишы вопросительные

sual' sözleri soru sözcükleri вопрогительные слова

sual' zamiri soru adılı, soru zamiri вопросительное местоимение, местоимение вопрогительное

sub'yekt özne подлежашее

suffiks sonek, son ek суффикс.

suffikssiz eksiz бессуфффиксный

sun'iy til' yapay dil искусственный язык

sun'iy tiller yapma diller я.зыки искусственные

$\$$

şahı̣ıs kişi, şahıs лишо

şahıs adı kişi adı, şahıs adı имя личное

şahıs affiksi kişi eki окончание личное

şahıs affiksleri kişi eki, şahıs eki личное окончание

şahıs zamiri kiși adılı, kiși zamiri, şahıs zamiri ıестоимение личное, личное мегтоимение

şahıslı cumle özneli cümle литюе прелпожение

şahıssız kişisiz, şahıssız безличный

şahıssız cumle kişisiz tümce, öznesiz cümle безличюое предложение

şahıssız fiil' şahıssız eylem. kişisiz fiil глагол безличный, безличный глагол

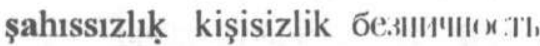

şart koşul, şart условпын

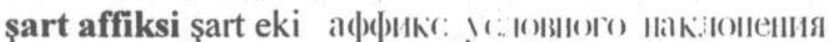

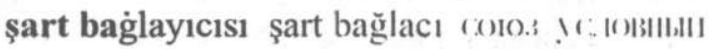

șart bildirgen al sözü șart tümleci по̆ топте:н,:Тво условия

şart cumlesi koșul cümlesi. varsàımısal tümce, șart cümlesi

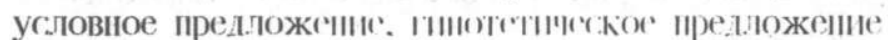

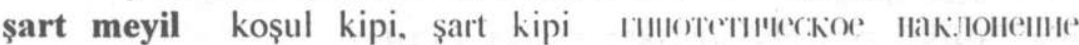

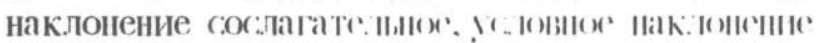


şimdiki zaman geniş zaman, şimdiki zaman времः ная:тояшеe, настояше время, презенс.

şive ağız, lehçе говор, диалешт, наречие

şuvultı gürültü шум

şuvultılı tutuk gürültülü ünsüz шумный согласный

$\mathbf{t}$

tabi cumle dilek cümlesi ,yan cümle, yantümce придаточное предложение

tabi oluv bağımlılık, bağlılık подчинение

tabili murekkep cumle girişik karmaşık tümce, girişik karmaşık cümle сложноподчинённое предложение

tabirli lugat ansiklopedik sözlük толковый словарь

taklidi taklidî, yansıma звукоподражание

taklidiy söz yansıma sözcük звукоподражательное слово

talil' analiz, çözümleme pa:збор

tamamlangan belirtilen, nitelenen, tamlanan определяемое

tamamlayıcı nesne, tümleç, niteleyici определение, дополнение

tam cumle tam cümle, tam tümce полное предложение

tam manalı söz tam anlamlı sözcük полнозначное слово

tam olmagan cumle eksik cümle, eksik tümce, kesik cümle дефектное предложение, неполное предложение

tamır asıl, kök, taban, temel корень, основа

tamırdaş kökteş однокорневой

tamırdaş sözler kökteş sözcükler однокорневые слова

tañlay damak нёбнО

tañlay aldı tutuk ön damak ünsüzü переднеязычный согласный

tañlay artı art damaksıl, artdamaksıl, dilardı damak задненёбный

tañlay artı tutuḳ art damaksıl ünsüz заненёбный гласные

tañlay sesi damaksıl ses нёбный звук

tañlay tiş tutuḳlan damak diş ünsüzü нёбно-зубной гогласный

tañlay tutukları damak ünsüzleri, dil ardı ünslizleri : қанеязычный гогласные

taralma büzülme, daralma сужение

tar sozuk dar ünlü закрытый гласный,у:зкий гласный

tarihiy tarihsel исторический 
tarihiy grammatika artzamanlı dilbilgisi, tarihî gramer, tarihsel dil bilgisi исторический грамматика, грамматика историческа я

tarihiy til ilimi tarihsel dilbilim исторический лингвистика

tarlaşuv büzülme, daralma сужение

tarz alı durum belirteci, hal zarfı, niteleme belirteci наречие образа действия

tarz bildirgen al sözü hareket tümleci обстоятельство образа действия

teklik sayı tekil единственное число

tekmil kanun, kural закон

telaffuz söyleyiş, telaffuz прои:зношение

tembr tını тембр

teñeştirme, ol'çeştirme karşıllaştırma сопогтавление

teñeştirüv ekvatif, eşitlik, mukayese, karşılaştırma сравнение, эКватив

teñeştirüv kelişi eşitlik hali эквативный падеж

teñeştirüv munasebetçileri karşılaştırma edatları сравнительные поглелоги

teñeştirüv yalgaması eşitlik eki эКвативный афФикс.

tercime aktarma, çeviri, tercüme перевод

termin terim термин

tez yazı hızlı yazı, yalın yazı скоропись

tırnaklar tırnak işareti кавычки

til' dil, söz речь, язык

til' ailesi dil ailesi семейство языков, языковая семья

til' artı arka damak, dil ardı заднеязычный

til' artı sesi - dilardı sesi велярный звук

til' artı sozuk dil ardı ünlüleri заднеязычный гласные

til' artı tutuḳları damak ünsüzleri, dil ardı ünsüzleri заднеязычный гогласные

til' atlası dil atlası языковой атлас.

til'de alınmalar aktarma sözcük, alıntı sözcük заимствование слово

til' ucı tutuklan dilucu ünsüzleri апикаль, корональные согласные

tire tire тире

tiş diş зуб

tiş eti diş eti, dişsil альвеолярный

tiş eti tutuḳı diş eti ünsüzü, dişsil ünsüz альвеолярный согласный 
tişli dişsil зубной, дентальный

tişli tutuk dişsil ünsüz, diş ünsüzüi дентальный согласный, зубной согласный

toḳtav işareti noktalama işareti знаки препинания

tolu cumle tam cümle, tam tümce полное предложение

ton perde, ton интонашия, тон

toplulık sayılan topluluk sayıları собирательные числительное, числительное собирательные

toponimika yer adları bilgisi, yer adları bilimi топонимика

transkriptsiya çeviri yazı, çevriyazı, transkripsiyon, yazı çevrimi транскрипшия

tutuk konsonant, ünsüz консонант, согласный

tutuk ḳoşuluvı ünsüz türemesi прибавление согласного

tutuklarnı̃ garmoniyası ünsüz uyumu гармония согласных

tutuklarnñ uygunluġı ünsüz uyumu гармония согласных

tutuk nevbetleşüvi ünsüz almaşması, ünsüz göçüşmesi чередование гогласных

tutuk türlenüvi ünsüz değişimi и:менение согласного

tuvganlık isimleri akrabalık adları имена обозначаюшие родсвенн е гвязи

türlenmegen söz çekimsiz sözcük неизменямые слова

türlenüv ad çekimi, çekim, çekimleme, değişim, değişme изменение, глряжение, гклонение

türlenüv yalgaması çekim eki аффикс. гклонение

tüslengen fiil' çekimli fiil глагол финитно

tüslenmegen fiil' çekimsiz fiil глагол инфинитно, неглрягаемая глагол

tüslenüv çekim, çekimleme глряжение

täşken ses düşmüş ses выпадаюший звук

tüşüm alı belirtme hali, belirtme durumu, yükleme hali винительный падеж

tüşüm keliş belirtme durumu, belirtme hali, yükleme hali винительный падеж, падеж винительный

täșän kavram понятие 
$\mathbf{u}$

uçünci şahıs üçüncü kişi, üçüncü şahıs лицо третье, третье лицо ufak arif küçük harf строчная буква

ufak til'çik küçük dil маленький я.љычок

umumiy mupteda ortak özne обшее подлежашее

umumiy genel обший

umumiy ob'yekt ortak nesne обшее дополнение

umumiy til' genel dil я.зык обший, обший я.зык

umumiyleştirici sözler genellemeli sözcükler, genelleştirici sözcükle обобшаюшие словарь

urgig vurgu ударение

urg̀u işareti vurgu işareti :нак ударение

urg்ulı vurgulu ударный

urgulı eca vurgulu hece, vurgulu seslem ударный слог, слог ударный

urgusız vurgusuz безударный, неударный

urğusız eca vurgusuz hece, vurgusuz seslem слог безударный, безударный слог

ust' tişler üst dișler верхняе зубы

ustünlik derecesi en üstünlük derecesi превогххоная стегіень uvula küçük dil маленький я.ычоК

uyġunlı̣ uygunluk, uyum гармония, согласование

uzun uzun долгий

uzun eca uzun hece долгий слог

uzun sozuk uzun ünlü долгий гласный

uzun tutuk uzun ünsüz долгий согласный

$\mathbf{v}$

vaḳıt bildirgen al sözü zaman tümleci обстоятельство времени vaḳt bildirgen zarflar zaman belirteci, zaman zarfı наречие времени variant değişke, varyant вариннт

vasta keliş araç durumu, vasıta durumu, vasıta hali падеж инструментальный, инструментальный падеж

vasta til' aracı dil я:ык посредник, погредствуюший я.ык

vastalı tamamlayıcı dolaylı nesne, dolaylı tümleç когвенное дополнение 
vastasız tamamlayıcı dolaysız tümleç, düz tümleç прямое управление

virgul' virgül :

vokalizm ünlüler sistemi вокализм

vulgarizm argo вульгари.зм

$\mathbf{y}$

yalgama ek, takı aффикс.

yalgamasız eksiz бехћффиксный

yańġıavuk ötümlü, sedalı, tonlu, sesleme, tınlama звучание, ЗВОНКИЙ

yafig̀ıravuḳlaşma ötümlüleşme, sedalılaşma, tonlulaşma озвончение

yafiıravuḳlı̣ titreşimlilik звучность

yaffġravuk tutuḳ ötümlü ünsüzler звонкие согласные

yapma söz türeme sözcük, türev производное слово

yapma tiller yapma diller я.зыки искусственные

yardımeı yardımcı всломогательный

yardımeı fiil' yardımcı eylem, yardımcı fiil всломогательный глагол

yardımeı ses bağlayıcı ses, yardımcı ses вставной звук

yardımeı sozuk yardımcı ünlü дополнительный гласный

yardımcı söz yardımcı sözcïk всломогательный слово, служебный. слово

yan sozuk yarı ünlü полугласный

yarim cumle eksik tümce недостаточное предложение

yarm sozuk yarı ünlü глайд

yazı yazı, yazıt надписть, писменность

yazı tili yazı dili, yazın dil литературный язык

yazısı olgan tiller yazılı diller писменнные язлыки

yer alı bulunma durumu, bulunma hali, kalma durumu местный падеж

yer bildirgen al sözü yer tümleci обстоятельство места.

yer bildirgen zarf yer belirteci, yer zarfi наречие места

yer kelişi bulunma durumu, bulunma hali, kalma durumu местный

- падеж, падеж местный, локатив

yerli şive yöresel diyalekt местный диалект

yımşak ince мягкий 
yımşak ince sıra передний ряд

yımşak sozuk ince ünlü, ön ünlü гласные мягкие, мягкие гласные yımşak tutuk ince ünsüzler мягкие согласные

yımşak tañlay yumuşak damak мягкое нёбо

yoḳluk cumleleri olumsuz cümle отришательное предложение

yoḳluk zamiri olumsuzluk adılı, olumsuzluk zamiri местоимение отришательна, отрицательное местоимение

yukarı sozuḳ dar ünlü у:зкий гласный

yükletüv ettirgen кау:хатив

yükletïv derece ettirgen çatı побудительный :алог

yükletüv derece yalgaması ettirgenlik eki, faktitif eki аффикс понудительного :алого, кау:зативный аффикс

$\mathbf{z}$

zaman zaman время, временной

zaman affiksi zaman eki аффикс. времени

zaman baġlayıcısı zaman bağlacı сою: временной

zaman cumlesizaman cümlesi, zaman tümcesi временной предложение

zaman tabi cumle zaman cümleciği придаточноепредложениевремени

zamir adıl, zamir местоимение

zarf belirteç, zarf наречие

zenaat-uner ismi meslek ismi названия профессии и ремёсел 


\section{Türkçe Dizin}

a

abartma giperbola

abece alfavit, elifbe

açı doġrudan doğru

açık hece açı̣ eca

ad ad, isim

ad çekimi türlenüv

ad gövdesi isim negizi

ad kökü isim tamırı

ad tümcesi ismiy cumleler

addan türeme ad isimden

yapılgan isim

addan türeme eylem isimden

yapılgan fiil'

adıl zamir

adlandurma nominatsiya

ağız aġız, şive

ağız boşluğu aġız boşluğı

ağız sesi aġı sesi

ağızlaşma ag̉ı sesine keçüv

ağzın açılma derecesi

aġıznıñ açılışı

akıcı kaçak

akıcı sesler kaçak sesler

akıcı ünlü ḳaçaḳ sozuḳ

akıcı ünsüz sonorlı tutuḳlar

akraba diller aḳraba tiller

akrabalık adlarin tuvganlık

isimleri

aktarım alınma, tercime, metafraza

aktarma sözcük til'de alınmalar

aktif sözlük aktiv lugat

akustik akustika alfabe alfavit, elifbe

alıntı alınma

alıntı sözcük til'de alınmalar

alofon fonemanıñ türleri

alomorf morfemanı̃ türleri

alt çene alt (aşağı) çenge

alt dudak alt (aşag̀ı) dudak

amaç zarfi makssad bildirgen

zarf

ana baş

ana cümle baş cumle

ana dil ana til'

ana dili ana tili

ana vurgu asıl urgu

analiz analiz, talil'

anatümce baş cumle

anlam aktarması anlam

avuşturuv

anlam atlaması metafora

anlam bilimi semantika

anlam daralması mananıñ

tarlaşuvı

anlam değişmesi mana

türlenüvi

anlam mana

anlambilim semantika

anlamdaş manadaş

anlamdaş sözcükler manadaş

sözler

anlamdaşlık manadaşlık

anlamlı manalı

anlamlılık manalılık

anlatım ibare; ifade

ansiklopedik sözlük entsiklo-

pedik lugat, izaiy (tabirli)

lugat

a-okunuş a-laşḳan

ara ayırıcı, kiriş, pauza 
ara cümle kiriş cumleler ara sözcük kiriş söz araç durumu vasta keliş aracı dil vasta til' aratümce kiriș cumleler argo argo, vulgarizm arka damak til' artı arka damak n'si burun n'si arka sıra art sıra arkaik sözcük eskirgen söz art avurt kattı

art avurt ünsüzü aġı boşlug̀ tutuḳları, ḳattı tutuḳ

art damaksıl tañlay artı artdamaksıl tañlay artı art damaksıl ünsüz tañlay artı tutuk

art sira art sira

art sıra ünlüsü art sıra (ḳalın, ḳattı) sozuk

artlaşma art sırag̉a keçüv artzamanlı dilbilgisi tarihiygrammatika

asıl baş, tamır

asıl öge baş aza

asıl sayı miḳdar sayısı

asıl sayı sıfatı miḳdar sayılar

asıl vurgu asıl urgu

aslî ses asliy ses

aslî uzunluk asliy uzunlık

atasözü atalar sözleri

avurt ag̉ı boşlugi

avurt sesi ag̉ız boşlug̉ı sesi aykırılaşma dissimilyatsiya ayraç skobka, ḳavuz ayrilma durumu çıḳış kelişi(alı) ayrılma hali çıḳış kelişi(alı) azlık çokluk zarfı miḳdarderece zarfi

b

bağımlılık tabi oluv

bağımsız sözcük ayrı manalı söz

bağıntılama bag்

bağlaç bag̉layıcı

bağlaçsızlık bag̉layıcısızlık

bağlam kontekst

bağlama bag்

bağlama ünlüsü ḳoşuvcı

sozuk

bağlantı bag

bağlantılı diller agglütinativ

tiller

bağlayıcı ses yardımcı ses

bağlılık tabi oluv

baş harf buyük arif

baş öge baş aza

basit yüklem adiy haber

basit cümle sade cumle

basit tümce adiy cumle

basit zaman adiy zaman

basmakalıp klişe

başta ünlü türemesi proteza belgisiz belgisiz

belgisizlik adılı bel'gisizlik zamiri

belirli ad öbeği belgili isimli söz biriküvi

belirli isim tamlaması belgi-

li isimli söz biriküvi

belirli nesne belgili

tamamlayıcı

belirsiz belgisiz 
belirsiz isim tamlaması belgisiz isimli söz biriküvi belirsiz nesne belgisiz

tamamlayıcı

belirsizlik zamiri bel'gisizlik zamiri

belirsizlik zamiri belgisizlik zamiri

belirtec zarf.

belirten ayırıcı

belirtilen tamamlangan

belirtili nesne belgili

tamamlayıcı

belirtisiz isim tamlamas belgisiz isimli söz biriküvi

belirtisiz nesne belgisiz

tamamlayıç

belirtke işaret

belirtme durumu tüşüm(alı)

keliși

belirtme hali tüşüm(alı) kelişi

benzerlik eki beñzetüv (oh-

şav) yalġaması

benzeşme assimilyatsiya

benzeșmezlik dissimilyatsiya

benzetme eki beñzetüv

(ohșav) yalgaması

biçem stil'

biçem bilim stilistika

biçim forma

biçimbilim morfologiya

biçimbirim morfema

biçimbirimcik morfemanıñ

türleri

bildirişim hạberleşme

bildirme haber

bildirme cümleși ikaye

cumlesi

bildirme eki haberlik affiksi bildirme kipi oluv (ikaye)

meyli, haber fiili

bildirme tümcesi ikaye

cumlesi

bileșik murekkep

bileșik tümce murekkep

cumle

bilgi veren informant

bilim dili il'miy til'

bir cins soydaş

bir dilli bir tilli

birey dili idiolekt

bireysel dil idiolekt

birinci kiși birinci şahıs

birinci șahıs birinci şaḥıs

birinci șahıs iyelik eki birinci

şaḥıs mulkiyet yalgaması

birincil ses asliy ses

birincil uzunluk asliy uzunlık

birleșik ad murekkep ad

birleșik ek murekkep (ḳoş-

ma) affiks

birleşik eylem murekkep fiil'

birleșik fiil murekkep fiil

birleșik isim murekkep ad

birleşik kelime murekkep söz

birleșik özne murekkep

mupteda

birleșik sözcük murekkep söz

birleșik tümce murekkep

cumle

birleșik yüklem murekkep

haber, koşma (murekkep) ha-

ber

birleșik murekkep

birleșim birleșme

birleșme birleșme, ses

biriküvi 
birleștirmeli alfabe çırmaşkan yazı

bitișik yazı çırmașḳan yazı

bitișimli diller agglütinativ tiller

bitmișlik durumu bitken al (vaziyet)

boğaz boġaz, ġrtlaḳ

boğazsıl bog̀azhı

boğazsıllaşma bog̉azlaşuv

boğumlama artikulyatsiya

boğumlanma noktası arti-

kulyatsiya yeri

bükümlü diller flektiv tiller bulunma durumu yer kelişi

(alı)

bulunma hali yer kelişi (alı)

burunsıl burunlı

buyruk kipi emir meyli

buyrum kipi emir meyli

büzülme taralma, tarlaşuv

c

canlı canlı

canlı dil canlı til'

canlılık canlılık

c

çakıșma ses biriküvi

çatı derece

çekim tüslenüv, türlenüv

çckim eki türlenüv yalgaması

çckimleme tüslenüv, türlenüv çękimli fiil tüslengen fiil'

çckimsiz fiil tüslenmegen fiil'

çekimsiz sözcük türlenmegen

söz.

çene çenge

cevap cümlesi cevap cumlesi cevap ünlemi cevap-tasdik

nidasi

çeviri tercime

çeviri yazı transkriptsiya

çevriyazı transkriptsiya

çift dudak çift dudaḳlı

çift dudak ünsüzü ḳoşma

(çift) dudak tutuḳları

çift ögeli cümle eki azalı

cumle

çift sayı ekilik sayı

çift sözcük çift söz

çift ünlülü diftong

çift ünsüzler çift tutuḳlar

çiftdudaksıl çift dudaḳlı

çıkma durumu çıḳış keli-

şi(alı)

çıkma hali çıḳış kelişi(alı)

cins cons

cins ad cons isim

cins isim cins isim

cinsiyet cons

cinsiyetsiz orta cms

çizgi sızıçıł

çocuk dili bala tili

çoğul ikinci kişi ekinci şaḥıs

çoḳluk

çok anlamlı çok manalı

çok anlamlı sözcük sözniñ

çoḳmanalılığı

çok anlamlılık çoḳ manalılık

çok dilli çok tilli

çok dillilik çoḳ tillilik

çok heceli çok ccalı

çok ögeli çok azalı

çok ögeli cümle çok azalı

cumle 
çokluk eki çoḳluḳ yalġaması, affiksi

çözümleme analiz, talil' cümle cumle

cümle bilgisi sintaksis

cümle içi anlam cumle manası

cümle ögeleri cumle azaları

cümle ögelerinin sıralanışı

cumle azalarınıñ sıralanması

cümle tonu cumle

intonatsiyası

cümle unsurları cumle azaları cümle vurgusu cumle urgusı

cümle yapısı cumle ḳuruluşı

cümlenin temeli cumleniñ temeli

cümlenin temel ögeleri

cumleniñ baş azaları

d

damak tañlay

damak diş ünsüzü tañlay tiş tutukları

damak ünsüzleri tañlay (til' artı) tutukları

damaksıl ses tañlay sesi

dar ünlü yukarı (tar) sozuk

daralma taralma, tarlaşuv

datif hali dogrultuv kelişi

değişim türlenüv, deñişüv,

deñişme

değişke variant

değişme türlenüv, deñişüv, deñişme

denek informant

devrik cümle inversiyalı

cumle

deyim ibare. idioma deyimler sözlüğü frazeologik

lugat

deyiș stil'

deyişbilim stilistika

diftong diftong

dikte dikte (imlya)

dil til'

dil ailesi til' ailesi

dil ardı til' artı

dil ardı ünlüleri til' artı tutuk

dil ardı ünsüzleri tañlay (til'

artı) tutuḳları

dil atlası til' atlası

dil ucu ünsüzü til ucı tutuḳı

dilardı damak tañlay artı

dilardı sesi til' ardı sesi

dilbilgisi grammatika

dilbilim lingvistika

dilbilimci lingvist

dilek cümlesi ,yan cümle, yantümce tabi cumle dilek cümlesi istek cumlesi

dilucu ünsüzleri til' ucu tutuḳları

direct dogrudan dogiru

diş tiş

diş dudaksıl dudaḳ-tişli

diş eti tiş eti

diş eti ünsüzï tiş eti tutuḳı

diş ünsüzü tişli tutuḳ

dişilik ḳadın cınsı

dişsil tiş eti, tişli

dişsil ünsüz tiş eti tutuḳı, tişli

tutuk

diyalog dialog

dizimsel sintaktik

dizin indeks

dolaylı anlatım ḳıya laf 
dolaylı nesne vastalı

tamamlayıcı

dolaylı tümleç vastalı

tamamlayıc

dolaysız dogrudan dogru

dolaysız anlatım koçürilme

laf

dolaysız tümleç vastasız

tamamlayıcı

dönüişlü çatı ḳaytım derecesi

dönüşlü eylem ḳaytım fiili

dönüşlü fiil ḳaytım fiili

dönüşlülükk ḳaytım

dönüşlülï̈k adılı ḳaytım

zamiri, oz'lük zamiri

dönüşlülük zamiri oz'lük

zamiri , ḳaytım zamiri

dudak dudak

dudak benzeşmesi dudak

singarmonizmi

dudak ünsüzü dudaḳlı tutuḳ

dudak uyumu dudak

singarmonizmi

dudaksıl dudaḳlı, çift dudaḳlı

dudaksıl ünlüler dudaḳlı

sozuk

dudaksıl ünsïzler dudaḳlı

tutuk

dudaksıllaşmàa dudaḳlaşuv,

dudaḳ sesine keçüv

durak pauza

durma pauza

durum keliș, al

durum belirteci al zarfitarz

alı

durum eki keliş (al) affiksi

durum pozitsiya durum takısı keliş (al) affiksi

düşmüşs ses tüşken ses

dïz anlam söz manası

düz tümleç vastasız

tamamlayıcı

düz ünlü dudaḳsız sozuk

düzenleme kaide

düzleşme delabializatsiya

e

edat munasebetçi, derecelik, söz og'ü yardımcısı

edebî edebiy

edebî dil edebiy til'

edilgen belgisiz derece

edilgen çatı belgisiz derece

edilgen eylem mecul (balgi-

siz) fiil'

edilgen fiil mecul (balgisiz)

fiil'

eğretileme metafora

ek affiks, yalgama

eklemeli dil agglütinativ tiller

eklemleme artikulyatsiya

eklemleme noktası artikul-

yatsiya yeri

eksik cümle tam olmagan

cumle, yarım cumle

eksik tümce tam olmagan

cumle, yarım cumle

eksiz suffikssiz, yalgamasız

ekvatif ekvativ, teñeștirüv

emir cümlesi emir cumlesi

emir kipi emir meyil

en üstünlük derecesi ustün-

lik(arttıruv)derecesi

eril cins erkek cinsı

erkeklik erkek cınsı

eşadlı omonim 
eş anlamlı manadaş

eş anlamlılık manadaşlık

eşitlik ekvativ, teñeştirüiv

eşitlik eki teñeştirüiv yalğa-

masi

eşitlik hali teñeştirüv kelişi

eski biçim arhaizm, eskirgen

söz

eskimiş sözcük eskirgen söz

eşleme ilyave

etimoloji etimologiya

etken aktiv

etken çatı malüm derece

etken eylem aktiv fiil'

etken fiil aktiv fiil'

ettirgen yükletüv

ettirgen çatı yükletüiv derecesi

ettirgenlik eki yükletüv

derece yalgaması

eylem fiil'

eylem çekimi fiil'lerniñ tüslenüvi

eylem cümlesi fiil' cumlesi eylem gövdesi fiil' negizi eylem kökü fiil' tamırı eylem tümcesi fiil' cumlesi eylemden türeme ad fiilden yapılgan isim

eylemden türeme eylem

fiilden yapılgan fiil'

f

faktitif eki yükletüv derece yalgaması

fisıltılı ses pisırdılı ses

fiil fiil

fiil çatısı derece

fiil çekimi fiil'lerniñ tüslenüvi

fiil cïmlesi fïil' cumlesi fiil gövdesi fiil' negizi

fiil kökü fiil' tamırı

fiilden fiil yapım eki fiil'den

fiil' yapıcı yalgama

fiilden fiil yapma fiil'den fiil' yapuv

fiilden isim yapım eki

fiil'den isim yapıcı yalgama

fiilden türeme fiil fiilden

yapılgan fiil'

fiilden türeme isim fiilden

yapılgan isim

fiilsiz fiil'siz

fonem fonema

fonetik fonetika

fonoloji fonologiya

g

geçiş keçiş, keçüv

geçişli ob'yektli

geçişli fiil keçici fiil'

geçişme ses biriküvi

geçişsiz ḳalıcı, obyektsiz

geçişsiz fiil kalıcı fiil'

geçme keçiş, keçïv

geçmiş zaman keçken zaman

gelecek zaman kelecek

zaman

gelecek zamanın hikayesi

murekkep kelecek zaman

fiiliniñ ḳatiy şekiliniñ vastasız

şekili

gelecek zamanın rivayeti

murekkep kelecek zaman

fiiliniñ katiy şekliniñ vastalı

şekili 
gelecek zamanın șartı murekkep kelecek zaman fiiliniñ katiy şekliniñ şart şekili

genel umumiy

genel dil umumiy til genellemeli sözcükler umumiyleștirici sözler geniș ünlü keñ sozuk geniş zaman kelecek zaman, şimdiki zaman

geniş zamanın hikayesi murekkep kelecek zamannın davimilik șekliniñ vastasız şekili genişletilmiș cümle keniş cumle genitif saiplik kelişi geniz n'si burun n'si geniz sesi burun sesi ,burunlı ses

genizsil burunlı genizsil ses burunlı ses genizsil ünsüzler burun tutukları

gereklik kipi kerek meyil gereklilik kipi kerek meyil gerileyici regressivlik gerileyici benzeșme regresivlik assimilyatsiyası giriș kiriș giriș cümlesi kiriş cumlesi girișik karmașık tümce tabili murekkep cumle gurtlak bogiaz, girtlak gurtlaksıl sesler gırtlak sesleri grrtlaksıl ünsüzler gırtlak ustüi tutuklanı gırtlaksıllașma kemirçek. sesi-

ne keçüv

gizli özne logik sub'yekt göçüşme metateza göçïşme, yer değiştirme seslerniñ yerlerini almaştıruvı görünüş aspekt, metateza gösterme adılı işaret zamiri gösterme sıfatı işaret sıfatı gövde negiz gürültï şuvultı gürülttülü ünsüz şuvultılı tutuk

\section{h}

hâl keliș, al hal eki affiks hal zarfı al zarfitarz alı halk dili halk tili halk sözcüğgi avam hạalḳ tili hançere bogiaz, ġrtlak hareket tümleci tarz bildirgen al sözii harf arif has isim has isim hece eca hece bölmesi eca ayırıcı hece düsșmesi eca tüșüvi hece kaynaşması eca biriküvi hece sinırı eca ayırıcı hece yitimi eca tüşüvi heceleme sözlerniñ ecalarga bölünüvi

hemze laringal' tutuk hipotez gipoteza hitap hitap hızlı yazı tez yazı 
1

islıklı fisıltılı

islıklı sesler fisıltılı sesler

i

iç içki

iç kafiye içki rifma

iç ses içki ses

iç ses düșmesi sinkopa

iç uyak içki rifma

içsel içki

içses içki ses

içses düșmesi sinkopa

içses yitimi sinkopa

ifade ibare; ifade

iki anlamlılık eki manalılık

iki dilli sözlük eki tilli lugat

iki dillilik eki tillilik

iki heceli eki ecalı

iki heceli sözcükler eki ecalı

sözler

iki nokta eki noḳta

iki ögeli cümle eki azalı

cumle

iki özneli cümleeki muptedalı cumle

iki yüklemli cümle eki

haberli cumle

ikili çatılı yüklem ekinci

derece haber

ikili konuşma dialü

ikinci çoğul kişi ekinci șaḥıs

çoḳluk

ikinci dereceli öge ekinci

derece aza

ikinci kişi ekinci şahı̣ıs

ikinci tekil kiși ekinci şaḥıs teklik ikinci teklik şahıs ekinci șahı̣ı teklik

ikincil uzunluk ekinci uzunlık ikizleşme geminatsiya

ilerleyici benzeşme progressivlik assimilyatsiya

iletişim haberleşme

ilgeç munasebetçi, derecelik, parça ,söz og'ü yardımcısı

ilgi adılı nisbiy zamirler

ilgi durumu saiplik kelişi

ilgi hali saiplik kelişi

ilgi zamiri nisbiy zamirler

ilk ses baş ses

imlâ imlya, dog̀ru yazuv, orfografiya

ince ince, yımşak

ince sıra og' sıra, yımşaḳ, incc ince sıra ïnlüler og' sıra

sozuklar

ince ünlü ince (yımşaḳ) sozuk

ince ünsïzler ince (yımşaḳ)

tutuk

incelme og' sıraġa keçüv

incleks indeks

ironi ironiya

isim isim

isim çekimi ismiñ türlenüvi

isim cümlesi ismiy cumleler

isim fil isimfiil

isim gövdesi isim negizi

isim tamlaması isim söz.

birleșmesi (birikmesi)

isim tïmcesi isim cumlesi

isimden türeme fiil isimden yapılgan fiil'

isimden türeme isim isimden yapılgan isim 
isimfiil infinitiv, isimfiil'

işaret işaret

işaret dili jestler tili

işaret sıfatı işaret sıfatı

ișaret zamiri işaret zamiri

ișitimsel akustika

ișlek önimli

ișlek olmayan ekler az

mahsullı suffiksler

iștaș çatı ortaklık derece

iştaş fiil ortaḳlık fiil'

istek cümlesi istek cumlesi

istek kipi istek meyil

ișteş ortaḳlı̣

işteș çatı ortaḳlıḳ derece

işteș eylem ortaḳlıḳ fiil'

ișteș fiil ortaklık fiil

iyelik adılı mul'kiyet zamiri

iyelik durumu saiplik keliş

iyelik ekleri mulkiyet

affiksleri

iyelik hali saiplik keliş

iyelik zamiri mul'kiyet zamiri

izafet izafet

j

jargon jargon

jargonizm jargonizm

k

kafiye rifma

kakafoni kakafoniya

kakışma kakafoniya

kalın sıra art sıra

kalınlaşma art sıraga keçüv

kalıtımsal genealogiyalık

kalma durumu yer keliși (alı)

kanun tekmil kapalı e kapalı e

kapalı hece kapalı eca

kapantılı patlayıcı

karşı tez antiteza

karşılaştırma teñeştirme,

teñeştirüv, ol'çeştirme

karşılaştırma bağlacı ayıruv

baglayıcısı

karşılaştırma edatları teñeştirüv munasebetçileri

karşılıklı ortaḳlık

karşıt anlamlı antonim, ḳara-

maḳarşisözler

karşıtlık bağlacı ḳarşı ḳuyuv

baglayıcısı

karşıtlık ilgeci ḳarşı ḳuyuv

baġlayıcısı

kavram bilim semasiologiya

kavram bilimci

semasiolog

kavram tüşün

kaynaşma ḳoşuluv

kelime söz

kelime grubu söz birleşmesi

(birikmesi)

kelime hazinesi leksika, lugat

terkibi

kesik cümle tam olmagan

cumle

kesir sayı sıfatları kesir

sayılar

kesir sayısı kesir sayısı

kesme işareti apostrof

ki bağlacı ki bag̉layıcısı

kılıș ismi isimfiil'

kip meyil

kiplik modallik 


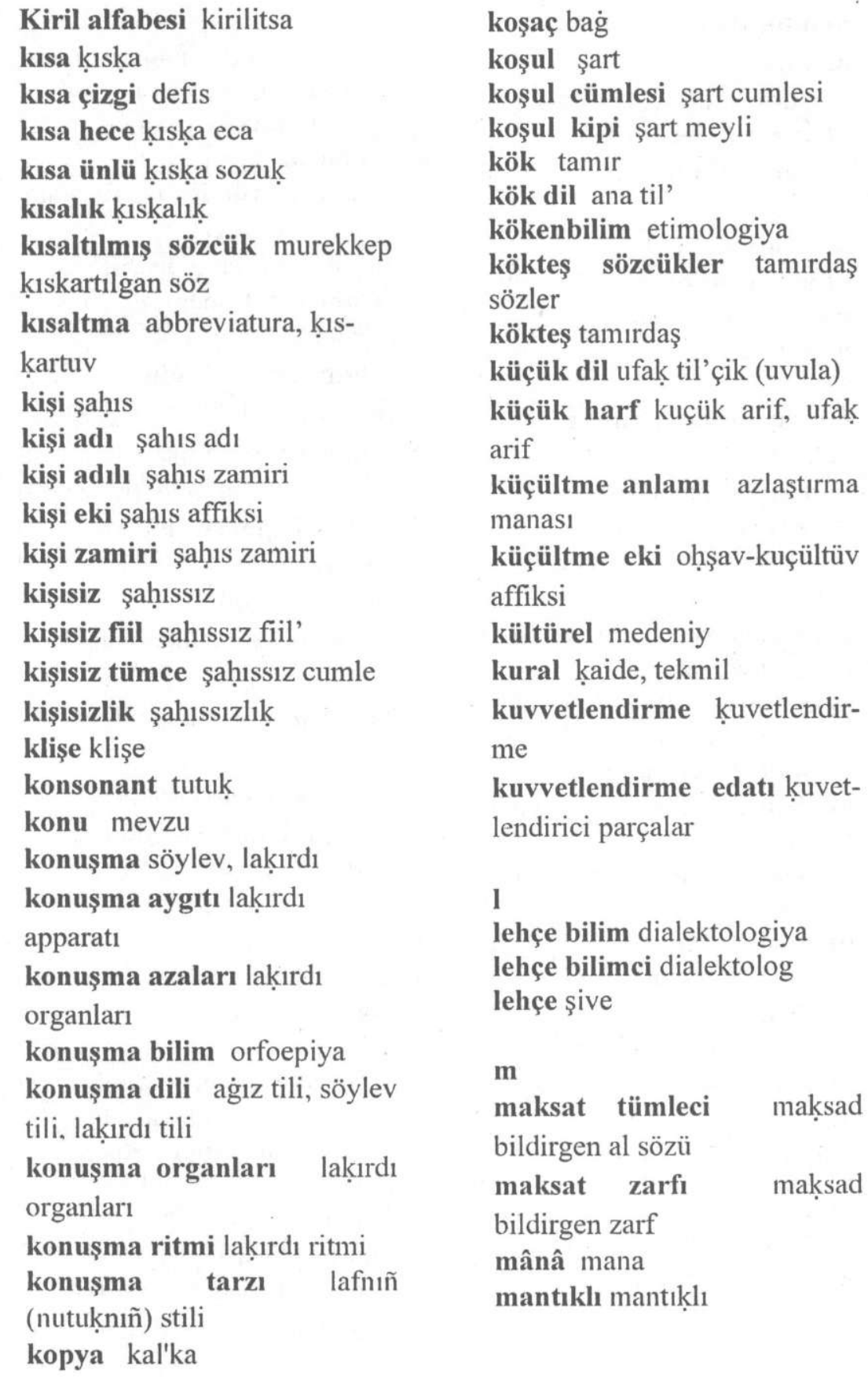


mantık vurgusu mantık

urgusı

mastar infinitiv, isimfiil

mecaz metafora

mecazî anlam almaştırılgan

mana

medenî medeniy

meslek ismi zenaat-uner ismi

metastaz metastaz

miktar zarfi ol'çü ve derece

zarfi

miktar-derece tümleci

mikdar-derce alı

millî dil milliy til'

mukayese teñeștirüiv

n

nazal ünsüzler burun tutukları

nesne tamamlayıcı

nesnesiz ob'yektsiz

niteleme adılı

ayırıcı-

umumileștirici zamir

niteleme belirteci al zarfi, tarz alı

niteleme sıfatı asıl (asliy)

sıfatlar

niteleme zamiri ayırıcı-

umumileștirici zamir

nitelenen tamamlangan

niteleyen ayırıcı

niteleyici ayırıcı, tamamlayıcı

nokta noḳta

noktalama işareti toḳtav

işareti

noktalı virgül noḳtalı virgül'

nutuk dili aǵı tili o

olumlu cümle musbet cumle olumlu fïil musbet fiil' olumlu tümce musbet cumle olumsuz menfiy

olumsuz cümle menfiy cumleler, yoḳluk cu

olumsuz fiil menfiy fiil'

olumsuzluk menfiylik, inkyar sözleri

olumsuzluk adılı inkyar zamiri, yoḳluk (menfiy) zamiri olumsuzluk zamiri inkyar zamiri, yokluk (menfiy) zamiri orta damaksıl ünsüz orta tañlay tutukıı

ortaç sıfatfiil

ortak nesne ortak, umumiy ob'yekt

ortak özne ortak,umumiy mupteda ortak yüklem ortak, haber ortaklaşma eki ortaḳlık yalgaması

ö

öbek ibare ödünç alınma öge aza öğrenilen geçmiş zaman sade keçken zamannıñ vastalışe ölçünlü söz bilim orfoepiya ölïi olï

ölï dil olü til

ölii ek olï affiks

ön avurt ünsïzï ag่ız boşlıgı ogi tutuḳı 
ön damak ünsüzü tañlay aldı tutuk

ön sesler ince sesler

ön türeme proteza

ön ünlü ince (yımşak ) sozuk

öndamaksıl ag̉ız boşluğı ogi

önek prefiks

önses baş ses

önses düșmesi baș ses tüșüvi

önsıra ünlüler og' sıra

sozuklar

örneklem paradigma

ötümlü yañgıravuk

ötümlü ünsüzler yañğıravuk tutuk

ötẗmlüleșme yañğıravuḳlaş-

ma

ötümsüz saġır

ötümsüz ünsüz saġır tutuk

ötümsüzleşme saġırlaşuv

ötümsüzlük saġırlık

öykünme kal'ka

özel ad has isim

özel isim has isim

özellik alyamet

özne mupteda, sub'yekt

özne yüklem uygunluğu

mupteda haber kelişiuvi

özneli cümle şahı̣ılı cumle

öznesi belli cümle belli șaḥsslı

cumleler

öznesiz muptedasız

öznesiz cümle şahı̣ıssız cumle

öznesiz cümleler muptedasız cumleler

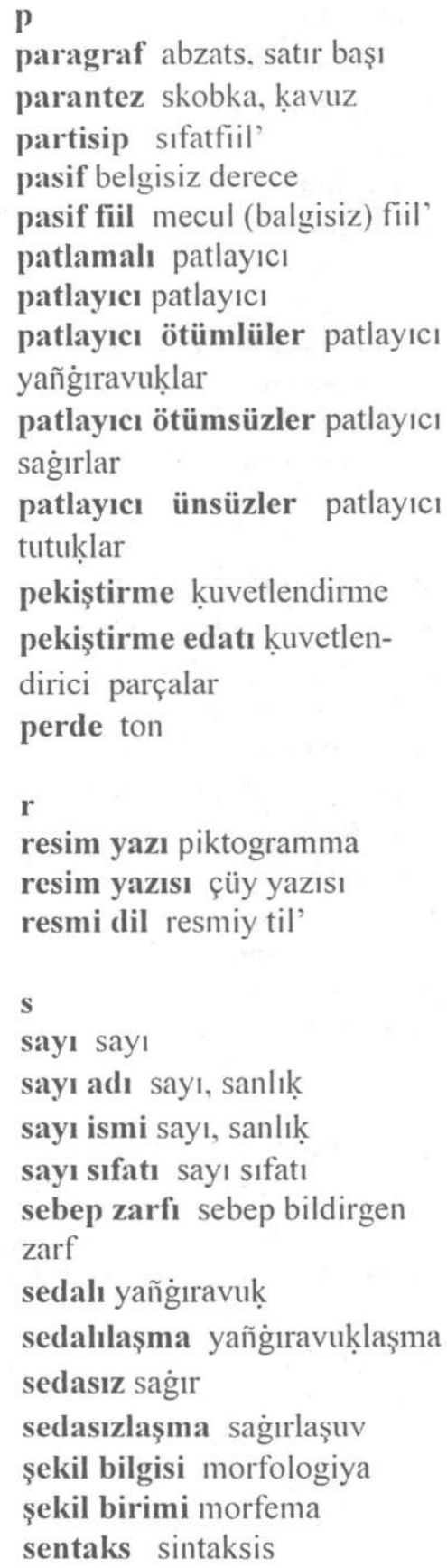


sert kattı

sert damaksıl kattı tañlay

sert ünsüz ḳattı tutuk

ses ses

ses bilimi fonologiya

ses birim fonema

ses birimsel değişke fonema-

nıñ türleri

ses birleşmesi ses biriküvi

ses birleșmesi ses birleșmeleri

birikmeleri

ses değişmesi ses türlenüvi

(deñişmesi)

ses düşmesi ses tüşüvi

ses örgenleri lakurdı organları

ses telleri ses bezleri

ses telleri ses bezleri

ses tonu ses tonu

ses türemesi ses ḳoşuluvı

ses uyumsuzluğu kakafoniya

ses uzunluğu ses uzunluğ

ses yitimi ses tüşüvi

ses yolu ses yolı

ses yüksekliği sesniñ yüksek-

ligi

sesbilgisi fonetika

sesbilim fonologiya

sesbirim fonema

sesbirimcik fonemanıñ türleri

sesin oluşumu seslerniñ

meydanga kel'mesi

sesin türemesi seslerniñ

meydanga kel'mesi

seslem eca

seslem yutumu eca tüşüvi

sesleme yañğravuk

seslemleme sözlerniñ ecalarǵa

bölünüvi seslenme hitap

sıfat sıfat

sıfat tamlaması sıfat söz

birikmesi

sıfat fiil sıfatfiil'

sinır ayırıcı

sira sira

sıra sayı sıfatı sıra sayısı

sıra sayısı sıra sayısı

sızıcı ünsüz sızġıravuḳ

tutuklar

soluk alma nefes aluv

soluk verme nefes çıḳaruv

soluk verme vurgusu nefes

çıḳaruv urgusı

somut ad konkret isim

somut anlam konkret mana

somut fiil konkret fiil'

somut isim konkret isim

son ek suffiks

sonek suffiks

son takı munasebetçi,

derecelik

soru sual'

soru adılı suạl' zamiri

soru cümlesi sual' cumlesi

soru edatı sual' parçaları

(derecelikleri)

soru eki sual' affiksi

soru ezgisi sual' intonatsiyası

soru ilgeci sual' parçaları

(derecelikleri)

soru işareti sual' işareti

soru işareti sual' işareti

soru sözcükleri sual' sözleri

soru tonu sual' intonatsiyası

soru tümcesi sual' cumlesi

soru zamiri sual' zamiri

soydaş genealogiyalık 
söyleyiş aytılış, telyaffuz soyut abstrakt soyut ad abstrak isim soyut anlam abstark mana soyut eylem abstrak fiil' soyut fiil abstrak fiil' soyut isim abstrakt isim söz laḳırdı, til, nutuḳ söz bilim ritorika söz öbeği ibare söz sanatı ritorika söz varlığı lugat terkibi söz varlığı leksika sözcük söz sözcük anlamı söz manası sözcük bilgisi leksikologiya sözcük bilimci leksikolog sözcük birleşimi söz terkibi sözcük çekimi söz türlenüvi sözcük dağarcığı leksika sözcük değişmesi söz türlenüvi

sözcük gövdesi sözniñ temeli, sözniñ negizi

sözcük öbeği söz birleşmesi (birikmesi)

sözcük türetici söz yapıcı

sözcük türetme söz yapuv sözcük türü söz çeşitleri sözcük yapımı söz yapuv sözdizimi sintaksis sözlük lugat sözlük anlamı lugat manası, sözniñ asıl-doginı manası sözlük bilimi leksikologiya sözlük düzeni sözlerniñ sırası
\$

şahıs şaḥıs

şahıs adı şahıs adı şahıs eki şaḥıs affiksleri şahıs zamiri şaḥı zamiri şahıssız şạ̣ıssız şahıssız fiil şaḥıssız fiil' şahıssız eylem şaḥıssız fiil' şart şart şart bağlacı şart bag̉layıcısı şart cümlesi şart cumlesi şart ekişart affiksi şart kipi şart meyli şart tümleci şart bildirgen al sözü

şimdiki zaman şimdiki zaman şive aktsent

t

taban tamır

takı affiks, türlenüv, yalgama

taklidî ses taḳlidi

taklit kal'ka

tam anlamlı ayrı manalı

tam anlamlı sözcük tam

manalı söz

tam cümle tam cumle, tolu

cumle

tam tümce tam cumle, tolu cumle

tamlanan tamamlangan

tamlayan ayırıcı

tamlayan durumu saiplik

kelişi

tarihî gramer tarihiy gram-

matika

tarihsel tarihiy 
tarihsel dil bilgisi tarihiy

grammatika

tarihsel dilbilim tarihiy til

ilimi

tarz stil

tek anlamlı bir manalı

tek anlamlılık bir manalılık tek dilli bir tilli

tek dilli sözlük bir tilli lugat

tek heceli bir ecalı

tek ögeli cümle bir azalı

cumle

tekil teklik sayı

telaffuz aytılış, telyaffuz

tema mevzu

temel baş, tamır

temel anlam asıl (dogru)

mana, asliy mana

temel cümle baș cumle

temel dil ana til'

temel tümce baş cumle

temel ünlüler asıl sozuklar

temel vurgu asıl urgiu

temel yüklem asıl haber

tercüme tercime

terim termin

tını tembr

tınlama yañgiravuk

tire defis tire

tırnak ișareti tırnaḳlar

titrek ünsüz ḳaltıravık tutuk

titremeli ünsüz kaltıravuk

tutuk

titremleme intonatsiya

titreșimli ses sonorlı ses

titreșimli ünsüz kaltıravuk

tutuk

titreșimlilik yañıravuḳlık ton ton

tonlu yañğıravuk

tonlulașma yañğıravuḳlaşma

tonsuz sag̀ır

tonsuzlașma saġırlașuv

topluluk sayıları toplulık

sayıları

transkripsiyon transkriptsiya

tümce cumle

tümce bilim sintaksis

tiimce ezgisi cumle

intonatsiyası

tïmce vurgusu cumle urgusı

tümleç al, al sözï,

tamamlayıcı

tür adı cıns isim

tïrdeș soydaș

tïreme negiz

türeme sözcük yapma söz

türemiș negiz

türev yapma söz, negiz

y

ulaç al añlatḳan fiil', alfiil'

uluslar arası sözcük inter-

natsional' sözler

uyak rifma

uygunluk uygunlık

uyum uyg̉unlık, aenkdeşlik,

garmoniy

uzun uzun

uzun hece uzun eca

uzun ünlü uzun sozuk

uzun ünsüz uzun tutuk

ii

üçüncü kiși uçünci șahı̣s

ïçüncï şahıs uçünci şaḥıs 
üleştirme sayı sıfatı pay sayı sifat

ünlem nida

ünlem cümlesi nida cumlesi

ünlem edatı nida parçaları

(derecelikleri)

ïnlem ezgisi nida intonatsi-

yası

ünlem ilgeci nida parçaları

(derecelikleri)

iinlem işareti nida ișareti

ïnlem tonu nida intonatsiyası

ïnlem tümcesi nida cumlesi

ïnlem tümcesi nida cumlesi

iinlii sozuk

ünlï almaşması sozuk nevbetleşüvi

ïnlü atlaması metafoniya

ünlü değişimi sozuḳ türlenüvi

ünlü düşmesi sozuḳ tüşüvi

ünlü göçüşmesi sozuk nevbetleşüvi

ünlü kısalığı sozuḳ ḳısḳalıġı

ünlï uyumu singarmonizm, sozuḳlarnıñ garmoniyası uygun

ünlü yitimi sozuk tüșüvi

ünlüler sistemi vokalizm

ïnlüleşme sozuḳlaşuv

ünsüz tutuḳ

ünsüz almaşması tutuk

nevbetleşüvi

ünsüz değișimi tutuk

türlenüvi

ïnsüz göçüşmesi tutuḳ

nevbetleşüvi ïnsüz türemesi tutuk

ḳoşuluvı

ïnsüz uyumu tutuklarnıñ

garmoniyasıuyġun

üretken önimli

üretkenlik önimlilik

üslup bilimi stilistika

üslup stil'

üst dişler ust' tişler

variant variant

varsayım gipoteza

varsayımsal tümce şart

cumlesi

vasıta durumu vasta keliși

vasıta hali vasta kelişi

verme durumu doğrultuv

kelişi

virgül virgul'

vokal sozuk

vurgu aktsent, urgu

vurgu işareti urgu işareti

vurgulu urg்ulı

vurgulu hece urğulı eca

vurgulu seslem urgulı eca

vurgusuz urgusız

vurgusuz hece urğusız eca

vurgusuz seslem urg̉usız eca

y

yabancı kelime ecnebiy

sözler

yabancı sözcük ecnebiy

sözler

yaklaşma hali dog̉rultuv

kelişi 
yalın yüklem adiy haber yalın cümle adiy cumle, sade cumle

yalın durum baș keliș (al) yalın hal baş keliş (al), nominatsiya

yalın isim sade isim

yalın tümce adiy cumle, sade cumle

yan ağız boşlugi

yan anlam almaştırılgan mana yansıma sözcük taklidiy söz yansıma ses taḳlidi yapay dil sun'iy til' yapım eki söz yapıcı affiks yapma diller yapma tiller, sun'iy tiller

yardımcı yardımcı yardımcı eylem yardımcı fiil' yardımeı fiil yardımcı fiil' yardımcı ses yardımcı ses yardımcı sözcük yardımcı söz yardımcı ünlü yardımcı sozuk yarı ünlü yarı sozuk, yarım sozuk yaşayan dil canlı til' yazdırma dikte (imlya) yazı yazı yazı çevrimi transkriptsiya yazı dili yazı tili, edebiy til' yazılı diller yazısı olgan tiller yazım imlya, dog̀ru yazuv, orfografiya

yazım kuralları orfografiya, imlya yazın dil yazı tili, edebiy til' yazit yazı yeni sözcük neologizm yer adları bilgisi toponimik yer adları bilimi toponimika yer belirteci yer bildirgen zarfyer değiştirme metateza yer tümleci yer bildirgen al sözü

yer zarfi yer bildirgen zarf yönelme durumu dogrultuv keliş

yönelme hâli dogirultuv keliş yönetici sözcük idare etici söz

yönetim idare, idare bag̀ 1 yönetme idare, idare bag̀ yöresel diyalekt yerli şive yüklem haber yüklem ismi haber ismi yükleme hali tüşüm(alı)kelişi yumuşak damak yımşaḳ tañlay

yuvarlak dudaḳlı

yuvarlak ünlü dudaḳlı sozuk yuvarlaklaşma dudaḳlaşuv, dudaḳ sesine keçüv

$\mathbf{z}$

zaman zaman

zaman bağlacı zaman bag̉layıcısı

zaman cümleciği zaman tabi cumle

zaman cümlesi zaman

cumlesi

zaman eki zaman affiksi

zaman tümcesi zaman

cumlesi

zaman tümleci vaḳıt bildirgen

al sözü

zamir zamir 
zarf zarf

zarf fiil al añlatḳan fiil', alfiil'

zit .ılamı. Intonim, ḳarama-

kä i sözler

7 anlamlılık ḳarşı manalılık

zıtlıı bağlacı ḳarşı ḳuyuv baġlayıcısı

\section{Rusça Dizin}

a

аббревиатура abbreviatura, kıskartuv

аб:яฺ abzats, satır başı

абгтрактный abstrakt

агглютинативный я.зык agglütinativ tiller

азбука elifbe

аканье a-lașkan

актив aktiv

активный словарь aktiv lugat актывный глагол aktiv fïil'

акустика akustika

акцент aktsent

алломорфа morfemanıñ

türleri

аллофона fonemanıñ türleri

а.лфавит alfavit, elifbe

а.львеолярный tiş eti

альвеолярный согласлый tiș

eti tutukı

анали: analiz

антите: ‘ी antiteza

антоним antonim, karama

ḳarşı sözler

антонимия ḳarşı manalılık

апикаль til ucı tutukı апостроф) apostrof

apro argo

артикуляния artikulyatsiya

архаизм arhaizm, eskirgen

söz

аслект aspekt

ассимиляшия assimilyatsiya

ассималяция горогрескивная progressivlik assimilyatsiya ассимиляшия регресиивная regresivlik assimilyatsiya аффикс, affiks,yalgama аффикс. времени zaman affiksi

аффикс. мпожествешноти çoḳluk yalgaması,affiksi аффикс образугоший глагол от глагола fiil'den fiil' yapıcı yalgama аффикс, образугоний имя от глагола fiil'den isim уарıс yalgama

аффикс: понулительного : лаго yükletüv derece yalgaması

аффикс. сказуемости haberlik affiksi

аффикс. склопение türlenüv yalgaması

аффикс: совместности ortaklıḳ yalgaması

аффикс условного паклонеІия şart affiksi

афџиксы падежей keliș affiksi

аффиксы принадлежности mulkiyet affiksleri 
аффиик:ы принадлежности пчуюое лииюо birinci şạ̣ıs mulkiyet yalgaması

б)

бю:џнии ḳaçak

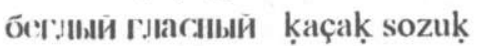
беныйе звуки ḳaçaḳ sesler бскиффиксиый yalgamasız безглаголный fiil'siz б:злипюе предложение șalụssız cumle

ӧ:зииинют:ть şaḥıssızlık

бен.иииныи şahııssız

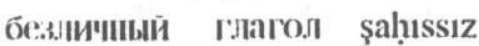

fiil'

ӧ:.обұ,ектішй ob'yektsiz

б:зударшый urgusız

безударный слюг urg்usız eca беххоюнный bağlayıcısızlık бегх:уфикг.шый suffikssiz бехподлежашщый muptedasız бехлодлежашпый

пелложепия muptedasız cumleler

билаббиалыный çift dudaḳlı

билабиалыный соглас:ный

ḳoșma (çift) dudaḳ tutuḳları

боковой ag่ız boşluġı

боковой звук aġız boșluġı

sesi

боковой сог:асыแй ag่ız

boșlugì tutuḳları

булушее время kelecek zaman будушее памерение murekkep kelecek zaman fiiliniñ ḳatiy şekliniñ vastasız şekili

будупее повегтвовательное время murekkep kelecek zaman fiiliniñ katiy şckliniñ vastalı șekili

будушее угыовное время murekkep kelecek zaman fiiliniñ katiy şekliniñ şart șekili

буква arif

B

вариант variant

вводное предложепие kiriş cumleler

вводюе слово kiriş söz

вводный kiriş

вдыхание nefes aluv

велярный звук til' ardı sesi

верхіяе зубы ust' tişler

в.яимный ortaḳlık

взаимный :залог ortaḳlı̣

derece

в.љрывпой patlayıсı

вз.рывные глухие patlayıс

saġırlar

в.зрывные :зволкие patlayıсı

yañgiravuḳlar

в.эрывные согласние patlayıс

tutuklar

винителыпый падеж tï-

şüm(alı)kelişi

вщутрешиый içki

впутриглагольюе fiil'den

fiil' yapuv 
внутристрочная рифма içki rifma

во:њратные мегтоимения

kaytım zamiri

возвратный ḳaytım

во:нвратный глагол kaytım

fiili

возвратный :алог kaytım

derecesi

вокали:єация sozuḳlaşuv

вокали:мм yokalizm

вокоид гласный sozuk

Bompor. sual'

вопросительная уастина

sual' affiksi

вопросителыне местоимение

sual' zamiri

вопрогительное

предложение sual' cumlesi

вопросительные слова sual'

sözleri

вопросительный :нак sual'

işareti

восклишание nida

восклишательное

предложение nida cumlesi

восклишательный :нак nida

işareti

вослрои:водимогть ӧnimlilik

пременной zaman

временюи предложение zа-

man cumlesi

время zaman

время будушее kelecek

zaman

время настоящеe şimdiki

zaman время прошедшее keçken

zaman

вслюмогательный yardımсı

всломогательный глагол

yardımcı fiil'

всломогательный слово yar-

dımcı söz

вставной :вук уardımcı ses

вторичная долгота ekinci

uzunlık

второе лищо ekinci şaḥıs

второе лицо единственшого

число ekinci şaḥıs teklik

второе лицо множегтвен-

ного писло ekinci şaḥıs

çokluk

второгтеленное сказуемое

ekinci derece haber

вульгари:м vulgarizm

выдох nefes çıḳaruv

выдыхание nefes çıkaruv

выдыхательное ударепие

nefes çıḳaruv urgusı

выпадаюший звук tüşken ses

выпадение гласного sozuk

tüşüvi

выпадение начального звука

baș ses tüșüvi

выражение ibare; ifade

высота:звукаsesniñ yüksekligi

Bяıłb çırmașḳan yazı

$\Gamma$

гаплология еса tüşüvi

гармония uyġunluḳ, aenkdeş-

lik, garmoniy 
гармония гласыых sozuklarnıñ garmoniyası, sozuḳlarnıñ uyg்unlugı

гармония согласлых tutuklarnıñ garmoniyası, tutuḳlarnıñ uyġunluġı геминашия geminatsiya генеллогический genealogiyalık генитив saiplik keliși герушлив alfiil' гипербол giperbola гипотеза gipoteza гипотетическое наклопение șart meyil

гипотетичегкое предложение şart cumlesi главное предложелие baş cumle главиое сказуемое asıl haber главпе ударепие asıl urgu главые улены предложе cumleniñ başazaları главныи baș глагол fiil' 1:ıгол абгтрактный abstrak fiil $^{\circ}$

глагол безлиины șaḥıssız fiil' глагол в:аимпый ortaḳlı̣ fiil

глагол возвраттแй kaytım fiili

глагол в страдлетелыюм a.jore mecul (balgisiz) fiil' піпюу⿰ ипфинитно tüslenmegen fiil' глагол конкретный konkret fiil' глаголиый корень fiil' tamırı глагол пепеу. 'ый kalıc fiil' глагол переходим fiil' глагол свя:зка al añlatḳan fiil' глагол транзитивный keçісі fiil' глагол финитно tüslengen fiil' глаголына основа fiil' negizi глагольне ими isimfiil' глагольное предложение fiil' cumlesi глаголыюе прилагательюе sıfatfiil' глагольный корень fiil' tamırı

глайд yarım sozuk гласыые мяагкие ince (yımşaḳ) sozuk гласный sozuk глосовые свялзки ses bezleri глухой saġır глухой соглас.ый sag̀ır tutuk глухогть saġırıł roßor aġı, şive голог, звук ses гологовой тоII ses tonu гологовые связики ses bezleri гортап!ая звуки ġrtlak sesleri 
гортань bogaz, ġrtlak

грамматика grammatika

грамматика историческая

tarihiy grammatika

губ dudak

губно-зубной dudaḳ-tişli

губной dudaḳlı

губной согласный dudaḳlı

tutuk

губные гласные dudaḳlı

sozuk

гуттурал bogaz

гуттурали:њиия boġazlaşuv

д

цательный падеж dogrultuv

kelişi

двазначногть eki manalılık

двоеточное eki nokta

лвойственное писло ekilik

sayı

двуподлежашиое предложе-

ние eki muptedalı cumle

двусказуемое предложение

eki haberli cumle

двуглоговой eki ecalı

двусложные слова eki ecalı

sözler

лвуязышие eki tillilik

двуязытний словарь eki tilli

lugat

деепричастие alfiil'

действительный қ.лог ma-

lïm derece

делабиали:зиия delabiali-

zatsiya

дентальный tişli дентальный согласный tişli

tutuk

дефектное предложение tam olmagan cumle

дефис. defis

диалект şive

диалектолюг dialektolog

диалектология dialektolo-

giya

диалог dialog

диктант dikte (imlya)

диссимилящия dissimilyatsiya

дифтонг diftong

долгий uzun

долгий гласный uzun sozuk

долггий глог uzun eca

долгий гогласлый uzun tutuk

долтота :зука ses uzunlugi

долженствовательне

паклоненение kerek meyil

лополиение tamamlayıсı

цополнительный гласный

yardımcı sozuk

дробное числительное kesir sayılar

дрожіший согласный kaltt-

ravuk tutuk

e

единственюе 'ислло teklik

sayı

ж

жаргоI jargon

жаргони:з jargonizm

желательне паклопение istek meyil

желательное предложепие istek cumlesi

женгкий род ̣ađın cınsı 
живой язык canlı til'

3

.หุा ภавна भ buyük arif

. илеенёбный tañlay artı

.илеешебшый гласыแе tañlay

artı tutuk

зялшеязытный til' artı

зилнеязынный гласыне til'

artı tutuk

.я диеязыпный ॥ burun n'si

: диеязыншый согласпые tañ-

lay (til' artı) tutuḳları

қалшый Гласлый art sıra

(kalın, kattı)sozuk

: жльый рял art sıra

қаимствование alınma

.иимствование глово til'de

alınmalar

.4koll tekmil

зикрытый гласныи tar sozuk

зикрытый слог kapalı еса

закрытый э kapalı e

؛алог derece

қилог в.иимиый ortaklık

derece

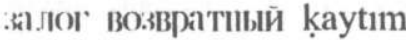

derece

ялюг действителынй та-

lüm derece

.йюГ глагола derece

ж.лог попудителыныи yükletiiv derece

.йюю страдателыныи belgisiz derece

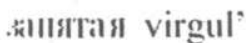

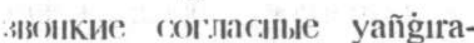

vuḳ tutuk
:३ЗНкий yañgiravuk

звук ses

звуки млгкие ince sesler

звуки ноговые burun sesi

звукоподражание ses taklidi

звукоподражателыюе слово

taklidiy söz

звукосочатание ses birleşme-

leri birikmeleri

звучиание yañğıravuk

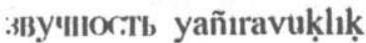

3І1ак işaret

зиак вогклицателыный nida işareti

зикк вопрогителный sual'

işareti

знаки препинапия toḳtav

işareti

зюак уларение urgu işareti

:аменателышые слова ауг

manalı söz

: аментелыный ayrı manalı

: เаташий manalı

: 1ичение mana

зачение абгтрактиое

abstark mana

: เачение конкретно konkret

mana

आанение лекгичегкое lugat

manası

: ичение ословне asliy

mana

: пение предложения

cumle manası

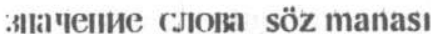

ऑเінимогть manalılık

зуб tiş

зуббой tişli 
зубной согласный tişli tutuk

и

илиолект idiolekt

идиома idioma

ияяфег izafet

ияменение türlenüv, deñişüv, deñişme

изменение глагыого sozuk

türlenüvi

изменение звука ses tür-

lenüvi (deñişmesi)

и.менение значение mana

tïrlenüvi

изменение гогласного tutuk

türlenüvi

и:ъявительное наклонение oluv (ikaye) meyli, haber fiili

изъявительный haber

имена обозначаюшие родс:-

вени е гвязи tuvganlık

isimleri

имелительный падеж baş

keliș (al)

именная огнова isim negizi

именное предложение ismiy

cumleler

именное сказуемое haber

ismi

императив emir meyil

имя isim

имя в огловном палеже

sade isim

имя лииное șahıs adı

имя наринателиюе cins isim

имя прилагетелюое sıfat

имя соб:твениое has isim

имя сушествитеныне isim имя числителыюе sayı,

sanlık

инвертированюе

предложение inversiyalı

cumle

инцекг. indeks

инлаут içki ses

иногтранюе слово есnebiy

sözler

инструмегталыный падеж

vasta keliş

интернашиональные глов

internatsional' sözler

интонация intonatsiya

интонания вопрогителына

sual' intonatsiyası

интонация вогклицательна

nida intonatsiyası

интонация предложения

cumle intonatsiyası

интоначия, тоI ton

ичџиичитив infinitiv, isimfiil'

иІгормалтт informant

ирония ironiya

искусттвенный яњык sun'iу

til'

исторический tarihiy

историчегкии грамматика

tarihiy grammatika

историчег:кий лингвистика

tarihiy til ilimi

исходый падеж çı̣ış

kelişi(alı)

$\kappa$

Кавычки tırnaḳlar

какафония kakafoniya

kal.ll,kal kal'ka

Kà.ıi'TuIs yïkletüv 
каузативный аффикс: yükletüv derece yalgaması

категтвенное

прилагательное asıl (asliy)

sifatlar

кирилиша kirilitsa

клинопись с̧ӥу yazısı

к.лише klişe

количегтвенное числителпое

mikdar sayılar

коммуникашия haberleşme

конвергентция ses biriküvi

колкретное имя konkret isim

конкретное :

mana

конкретное

сушестбительно konkret

isim

консонант tutuk

контекст kontekst

корень tamır

корональные согласдые til' ucu tutukları

когенная речь kıya laf

косвенне дополшение

vastalı tamamlayıcı

краткий kııḳa

краткий гласный ḳıș̣a

sozuk

кјаткий слог ḳısḳa eca

краткогтьь ḳısḳalık

краткогть гласыых sozuk

ḳısḳalıg’ı

культурный medeniy

.l

лабиалиъаиия dudak sesine keçüv лабиальные гласные dudaḳlı

sozuk

лабиалышые согласыые du-

daklı tutuk

лабиальный dudaḳlı

лабиальный с.ингармони:зм

dudak singarmonizmi

лекгика leksika

лекгиколог leksikolog

лексикология leksikologiya

лингвист lingvist

лингвистика lingvistika

литературный edebiy

литературный язык yazı tili, edebiy til'

лицо şahııs

лишо второе ekinci șahıs

лицо третье uçünci şahıs

лицо первое birinci şahıs

личное мегтоимение şaḥıs

zamiri

личное окончание şą̣ıs

affiksleri

личное предложепие şahıslı

cumle

логичегкий mantıklı

логичегкое ударение mantık

urgusı

локатив yer kelişi

M

малепькая буквд kuçük arif маленький язычок ufaḳ

til'çik (uvula)

междометие nida

междометиое предложение

nida cumlesi 
местный диалект yerli şive местный падеж yer kelişi (alı) место артикуляшия artikulyatsiya yeri

мегтоимение zamir мегтоимение возвратное oz'lük zamiri

мегтоимение вопрогительное sual' zamiri

мегтоимение личное şą̣ıs

zamiri

мегтоимение неопределёле-

ние bel'gisizlik zamiri

мегтоимение определителние

ayırıcı-umumileştirici zamir

мегтоимение отрицательная

yoḳluḳ(menfiy) zamiri

мег:тоимение

притяжательное mul'kiyet

zamiri

мегтоимение указятелыюе

işaret zamiri

метаста: metastaz

метате:k metateza

метафония metafoniya

метафора metafora

метафра:қ metafraza

мёртвый olï

мёртвый с:уффикс: olï affiks

мёртвый язык olü til'

многозначное слово sözniñ

çoḳmanalılığı

много.sначногть çok manalılık

многогложный çoḳ ecalı

многоточие çoḳ noḳta

многочленное предложенпое

çoḳ azalı cumle многочленный çoḳ azalı многоя.зычие çoḳ tillilik многояззычный çoḳ tilli модальность modallik моногиллаб bir ecalı морф)ема morfema морфология morfologiya мужгкой род erkek cınsı мяагкие гласные ince (yımşaḳ) sozuk мягкие согласные ince (yımşaḳ) tutuḳ мягкий ince, yımşak мягкий боковой согласный aġız boşlugı ogi tutuḳı мягкое нёбо yımşą̧ tañlay мягкое согласные yımşak tutuk .

H

надгорташиковие согласные ġrtlaḳ ustü tutuḳları

падписть yazı

назяльные согласные burun tutuḳları

на:звание ad, isim

на:звания проресгии и

ремёсел zenaat-uner ismi

па:зывное предложение sade cumle

паклонение meyil

наклопение соглагательное

şart meyil

паправительный падеж

doğrultuv kelişi

наречие zarf

наречие времени vaḳıt

bildirgen zarflar 
паретие, говор şive наречие количественое mikdar-derece zarfi наречие меры и степени ol'çü ve derece zarfi паречие мегта yer bildirgen zarf

паречие образя действия al zarfı, tarz alı

паретие причины sebep

bildirgen zarf

наречие цели makssad

bildirgen zarf

парицательное

гушествительное conıs isim народный я.зык hạaḷ tili шастояше время şimdiki zaman

Іlіууный язык il'miy til' Іачалыный звук baş ses национальный я.љык milliy til'

негубной глапный dudaḳsız sozuk

недоктато'ное предложение yarım cumle

пеизменямые глова türlenmegen söz

нелабиа.ли:зованный гласлый

dudaḳsız sozuḳlar

пеологизм neologizm

неоределение местоимение

belgisizlik zamiri

шеопеделёниый belgisiz

пекооммленое опелели-

телыне belgisiz isimli söz

biriküvi пеоформлегное прямое дополюение belgisiz tamam-layıс ıепереходный kalıcı, obyektsiz

неполное предложение tam olmaġan cumle

непродуктивныс аффиксы az mahsullı suffiksler

пепрои:зводюе сушестви-

тельное isim tamırı

песпрягаемал глагол tüslenmegen fïil

неударный urg்usız

нёбно-зубной согласный

tañlay tiş tutuḳları

пёбный звук tañlay sesi

ІІёбıю tañlay

Іикжняя губа alt (aşağı)

dudak

Іижняя челюг: alt (aşag்i)

çenge

поминащия nominatsiya

посовой burunlı

посовой :звук burunlı ses

o

обобшаюшие слова umumiyleştirici sözler

оборот речи ibare

образовапие звука seslerniñ

meydanga kel'mesi

обрапение hitap

обстоятели,:тво времени

vakıt bildirgen al sözü

обстоятельстьо, дополение

al, al sözui

обгтоятельство меры-стенсІ

mikdar-derce alı 
обгтоятельство места yer
bildirgen al sözï
обгтоятельгтво обра:қа
дейгтвия tarz bildirgen al
sözї

обгтоятельгтво условия şart bildirgen al sözü

обттоятельство цели makssad

bildirgen al sözü

обшее дополнение ortak, umumiy ob'yekt

общее подлежащее ortak, umumiy mupteda

общее гказуемое ortak,haber общий umumiy

общий язык umumiy til'

оглушение sagirlaşuv

огубление dudaḳlaşuv

однозначногть bir manalılık

однозначный bir manalı

однокорневой tamırdaş

однокорневые слова tamırdaş

sözler

одиородный soydaş

одногложный bir ecalı

одночленное предложение

bir azalı cumle

одноязыниый bir tilli

олноя:ыуный словары bir tilli

lugat

одушевлённость canlılıк

одушевлённый canlı

о.ณю॥чение уañg்

окониание affiks

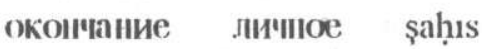

affiksi окончание падежное keliş

(al) affiksi

омогим отопim

определение ayırıcı, tamam-

layıcı

определённо-личное предло-

жение belli şahı̣slı cumleler

определительное словогочетапие sıfat söz birikmesi

определяемое tamamlangan

определяюшее ауıгıс

опрешение слогов еса

biriküvi

опущение слога eca tüşüvi

органы речевые lakırdı

organları

орфография orfografiya,

imlya

орфоэпия orfoepiya

основа tamır

оснога глагола fiil' negizi

основа, производный negiz

основа предложение cumleniñ temeli

основа слова sözniñ temeli, sözniñ negizi

основное гласиые asıl

sozuḳlar

основное значение asıl mana,

dogru mana

оснювное ударение asıl urg்

ответное предлюжение сеvар

cumlesi

открытый слог açıฺ̣ eca

отпогительное мегтоимение

nisbiy zamirler

отрипание menfiylik, inkyar sözleri 
отришательная форма глагола menfiy fiil'

отрицательное местоимение yoḳluk zamiri,inkyar zamiri отришательное предложение menfiy cumleler, yoḳluk cumleleri

отрицательный menfiy официальный я.зык resmiy til'

оформленное определительloe belgili isimli söz biriküvi оформленное прямое дополнение belgili tamamlayıсı ก

падеж keliş, al падеж винительный tüşüm keliş

падеж дательный dogrultuv keliş

падеж именителыный baș keliş падеж инструментальный vasta keliși

падеж исходий çıḳış keliş падеж мегтиый yer kelişi палежное окоп'апие keliş affiksleri

палеж родительный saiplik keliș

падение :звука ses tüşüvi паралигма paradigma парные слова çift söz гарные согласлые çift tutuḳlar пастив belgisiz derece กау:ณ̊ pauza первичная долгота asliy uzunlık первичное зиачение sözniñ asıl-doğn manası

первое лицо birinci şahı̣ı первоначальный звук asliy ses

перевод tercime передненёбный aġı boşlugi ogi переднеязычный согласный tañlay aldı tutuk передние гласные og' sira sozuḳlar передиий рял og' sıra, yımşak, ince переног. значения anlam avuşturuv переносное зиачение almaştırılgan mana перестановка звуков seslerniñ yerlerini almaștıruv переход keçiş, keçüv переход в задний ряд art sıraga keçüv переход в передний ряд оg' sıraġa keçüv переходый ob'yektli перфект keçken zaman пиктограмма piktogramma писменпогть yazı писменные язлыки yazısı olgan tiller побудительный :алог yïkletüv derece повелителыюе паклонение emir meyli 
повелительное предложеное emir cumlesi повегтвовательное предложение ikaye cumlesi подлежашее mupteda, sub'yekt

подчинение tabi oluv позишия pozitsiya полисемантический çoḳ manalı

полисемия çoḳ manalılı полисиллабический çok ecalı полное предложение tam cumle, tolu cumle полнозначное слово tam manalı söz положителыная форма глагола musbet fiil' полость рта ağı boşlugi полугласный yarı sozuk понудителный залог yükletüv derecesi

понятие tüşün

порядковое числительное sıra sayısı

порядок, рял sıra норядок слог sözlerniñ sırası поглелог munasebetçi, derecelik

пословица atalar sözleri погредствуюший яњык vasta til'

правило kaide

правописание imlya, dogru yazuv

пр:язык ana til'

прямая речь koçürilme laf грямое управление vastasız tamamlayıcı прямой dogrudan dog்ru превог:ходная степень ustünlik (arttıruv)derecesi преврашениев гортанный звук kemirçek sesine keçüv преврашениев ноцового вротовое aġı sesine keçüv предикат haber предлог söz og'ü yardımcısı. предложение cumle предложение вопросительное sual' cumlesi предложение безличное şаhı̣ssiz cumle предложение вводное kiriş cumlesi предложение двусоставное eki azalı cumle предложение простое adiy cumle предложение с. глагольным сказуемым fiil' cumlesi предложение с. именным сказуемым isim cumlesi пре:зенс. șimdiki zaman префикс prefiks прибавление збука ses ḳoşuluvı прибавление согласного tutuḳ ḳoşuluvı придато'пее предложение tabi cumle придаточное предложение времени zaman tabi cumle призиак alyamet прилагателюое sıfat 
приложение ilyave причастие sıfatfiil' продуктивный ӧnimli прои:зводное слово уарта söz прои:зодный negiz производный от глагола глагол fiilden yapılgan fiil' прои:зводный от глагола имя fiilden yapılgan isim прои:зодный от имены глагол isimden yapılgan fiil' прои:зодный от имены имя isimden yapılgan isim прои:ıюшение aytılış, telyaffuz произношение по слогам sözlerniñ ecalarǵabölünüvi простое время adiy zaman простое предложение adiy cumle прогторечие avam halk tili Іротећя proteza шрошелшее время keçken zaman пропедшее неопеделёнюе время murekkep kelecek zamannıñ dayimilik şekiliñ vastasız șekili прошедшее неочевидюе время sade keçken zamannıñ vastalı şekli

противителыный союз ḳarşı kuyuv baglayıcısı путь воздуха ses yolı p)

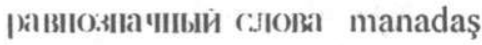
sözler разбор talil'

pa:sовор söylev, laḳırdı ра:говорная речь söylev tili, lakıırdı tili

разграничительный ayırıсı ра:зделительное тислителное pay sayı sıfatı расположение членов предложение cumle azalarınıñ sıralanması раслространённое предложенное keniş cumle par:тBop pтa ag่ıznıñ açılışı регрескивная ассимиляшия regresivlik assimilyatsiyası регрегсивный regressivlik речевой аппарат laḳırdı apparatı pe'ı laḳırdı, til, nutuk ритм речи lakırdı ritmi риторига ritorika рифма rifma род cins родителыный падеж saiplik kelişi

родной я.ык ana tili родсвешпые языка akraba tiller poт ag̀ı ротовой звук ag்ız sesi C. cвя.ska bag с.вभ.њb bag семантика semantika семасиолог semasiolog семасиология semasiologiya гемейстио языков til' ailesi 
(ингармониям singarmonizm

гинкопа sinkopa

синонимия manadaşlık

синонимический manadaş

синтагматический sintaktik

синтаксис sintaksis

гказуемое ḥaber

сказуемое простое adiy

haber

ска:зуемое составı̈ ḳoşma

(murekkep)haber

:клонение türlenüv

склонение сушествительного

ismiñ türlenüvi

с.кобка skobka, kavuz

скоропись tez yazı

скрытое подлежапее logik sub'yekt

словарный состав языка

lugat terkibi

гловарьlugat

словарь двуязычшый eki tilli

lugat

словарь одноязычегкий bir

tilli lugat

слово söz

словоизменение söz türlenüvi словообра:зование söz уарuv словообра:зовательный

аффикс söz уарıсı affiks

словопрои:зодный söz уарıсı

словогочетание söz birleș-

mesi (birikmesi)

словосочетание именное isim söz birleşmesi (birikmesi)

слог еса

слог безударный urgusı eca слогораздел еса ayırıсı слог открытый ас̧ı ḳ eca слог ударный urgulı eca сложное имя murekkep ad сложиюе предложение murekkep cumle сложное слова murekkep söz сложноподчинённое предложение tabili murekkep cumle слюжносокращённое слово murekkep ḳıskartılgan söz сложный аффикс murekkep (ḳoşma) affiks

сложный глагол murekkep fiil'

служебный слово yardımcı söz

смысл mana

собирательные числительное toplulık sayıları

собгтвенное имя has isim совершенный вид bitken al (vaziyet)

согласный tutuḳ

согласовапие uyğunlıḳ

согласование ска:зуемого с. подлежашим mupteda haber kelişüvi

соединительный гласный

ķoşuvcı sozuk

сонорный звук sonorlı ses

сонорный согласный sonorlı tutuklar

сопоставление teñeştirme, ol'çeştirme 
гогтавное подлежашее murekkep mupteda гогтавное гказуемое murekkep haber составной murekkep согтав словарный söz terkibi сочетание birleşme сою:s baglayıcı союз временной zaman baġlayıcısı

гоюз ки ki baġlayıcısı союз противителыный ূarşı kuyuv bag̀layıcısı сою:s разделитепыный ayıruv bağlayıcısı

сою: условный şart bag̉a-

yicisı

гпряжение tüslenüv, türlenüv слряжение глагола fiil'lerniñ tüslenüvi

гравнение teñeştirüv

сравнительные поглелоги teñştirüv munasebetçileri гредненёбный согласный orta tañlay tutuḳı

г.редиий род orta cıns стилистика stilistika г:тиль stil' я:тиль разговорный lafnı̃̃ (nutuḳnıñ) stili

ггроение предложения cumle ḳuruluşı строчна я буква ufak arif стяжеıие k़oşuluv сужжение taralma, tarlaşuv сужение : tarlașuvı с:уффикс: suffiks сушествительное isim существительное абстрактное abstrakt isim г.ушегтвительное нарицательное cıns isim $T$

твёрдонёбный kattı tañlay твёрдый kattı твёрдый согласный ḳattı tutuk тема mevzu тембр tembr термин termin тире tire толковый словарь izaiy (tabirli) lugat TOH ton топонимика toponimika TO'ка noḳta точка с. :апятой noḳtalı virgül' трангкрипшияtranskriptsiya третье лицо uçünci şahııs $\mathrm{y}$

ударение urgi ударный urgulı ударный слог urgulı еса у:зкий глас:њый yukarı (tar) sozuk ука:қтельное местоимение işaret zamiri ука:қтелыюе слово işaret sıfatı умешшителыюе :пачение azlaştırma manası 
уменшительно-ласкателылый аффикс: ohșşav-kuçültüv affiksi

уподобительный аффикс. beñzetüv (ohşav) yalgaması управление idare, idare bag̀ управляюшее слово idare etici söz

усиление kuvetlendirme усилительная частица $\mathrm{ku}-$ vetlendirici parçalar (derecelikler)

угловный şart

условное наклонение șart meyli

условное предложение şart cumlesi

устаревшия слово eskirgen

söz

устная речь ag்ız tili

утвердителыне междометие cevap-tasdik nidası

утвердителыне

предложение musbet cumle $\phi$.

флективные языки flektiv tiller

фонема fonema

фонетика fonetika

фонология fonologiya

форма forma

фра:* ibare

фра:зеологичегкий словари frazeologik lugat

фра:зовое ударение cumle urgusı
$\mathrm{X}$

Хaм:หৈ laringal' tutuk

художествешнй язык edebiy til'

I

части речи söz çeșitleri частица parça, derecelik частишы вопрогителышые sual' parçaları (derecelikleri) частицы восклицсательные nida parçaları (derecelikleri) челюс: çenge

чередование гласыь sozuk nevbetleșüvi

чередование согласных tutuk nevbetleşüvi

чёрто'ıка sızıçık

числительное sayı sıfatı

числителыюе дробюое kesir sayısı

числительное

количественпо mikdar sayısı числительне порядковое

sıra sayısı

числителыюе собирателыные topluluk sayısı

'исло sayı

член aza

члеп второстепепшй ekinci derece aza

член главный baş aza

члены предложения cumle azaları

III

щёпотный звук pısırdılı ses шипящие звуки fisıltılı sesler щипящий fısıltılı широкий глас:њй keñ sozuk 
IIIy. şuvultı

ІІумный согласный şuvultılı tutuk

III

ıщелевой согласный sığ̀ravuk tutuklar

3

эКватив ekvativ, teñeștirüv

эквативныи аффикс: teñeştirüv yalgaması

экњатищнй падеж teñeștirüv kelişi

эппиклопедический словарь entsiklopedik lugat этимология etimologiya
II

ЯЗЗाК til'

язык детей bala tili

язык жестов jestler tili

язык живой canlı til'

языки искусственшые уарта

tiller, sun'iy tiller

язык литературный edebiy til'

Язык обший umumiy til' пзыковая семья til' ailesi я.зыковой атлас: til' atlası язык посредник vasta til' язык родпой ana tili 